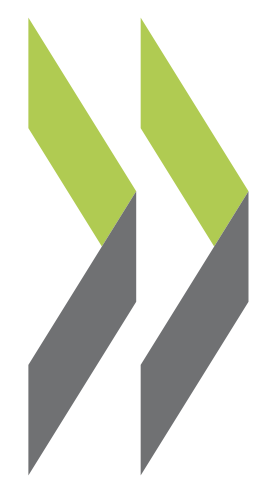

OECD Economics Department Working Papers No. 837

The Price Responsiveness
of Housing Supply in OECD Countries

Aida Caldera Sánchez, Asa Johansson 
Organisation de Coopération et de Développement Économiques

Organisation for Economic Co-operation and Development

26-May-2011

ECONOMICS DEPARTMENT

English - Or. English

Cancels \& replaces the same document of 18 January 2011

THE PRICE RESPONSIVENESS OF HOUSING SUPPLY IN OECD COUNTRIES

ECONOMICS DEPARTMENT WORKING PAPERS No.837

By Aida Caldera Sánchez and Åsa Johansson

All Economics Department Working Papers are available through OECD's internet web site at www.oecd.org/eco/workingpapers

JT03302412

Document complet disponible sur OLIS dans son format d'origine

Complete document available on OLIS in its original format 


\section{ABSTRACT/RESUMÉ \\ The Price Responsiveness of Housing Supply in OECD Countries}

The responsiveness of housing supply to changes in prices bears important implications for the evolution of housing prices and the speed of adjustment of housing markets. This paper estimates the long-run price elasticity of new housing supply in 21 OECD countries based on a stock-flow model of the housing market estimated within an error correction framework. Estimates suggest that housing supply responsiveness to price changes varies substantially across countries. New housing supply is relatively more flexible in North America and some Nordic countries, while it is more rigid in continental European countries and in the United Kingdom. The responsiveness of housing supply depends not only on national geographical and urban characteristics but also on policies, such as land use and planning regulations. The estimates are broadly in line with the limited available evidence on the responsiveness of housing supply in OECD countries.

JEL classification codes: R31, R21, R38, H11

Keywords: Housing supply; housing markets; house prices, land use regulation.

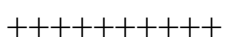

\section{La Réactivité de l'Offre de Logements dans les Pays de l'OCDE}

La réactivité de l'offre de logements à l'évolution des prix a des implications importantes pour l'évolution des prix du logement et la vitesse d'ajustement des marchés du logement. Ce document estime l'élasticitéprix à long terme de l'offre de nouveaux logements dans 21 pays de l'OCDE basée sur une approche stockflux du marché du logement et un modèle à correction d'erreurs. Selon les estimations, la réactivité de l'offre de logements aux changements de prix varie considérablement selon les pays. L'offre de logements nouveaux est relativement plus souple en Amérique du Nord et certains pays nordiques, tandis qu'elle est plus rigide dans les pays du continent européen et au Royaume-Uni. La réactivité de l'offre ne dépend pas seulement des caractéristiques géographiques et urbaines, mais aussi des politiques publiques, telles que les règles d'urbanisme et d'utilisation du sol. Les estimations sont globalement en ligne avec les rares estimations disponibles sur la réactivité de l'offre de logements dans les pays de l'OCDE.

Classification JEL : R23 ; R31 ; R21 ; R38 ; H20.

Mots-clés: Offre de logements : Marché du logement ; Prix des logements ; Règles d'utilisation du sol.

\section{Copyright OECD 2011}

Application for permission to reproduce or translate all, or part of, this material should be made to: Head of Publications Service, OECD, 2 rue André-Pascal, 75775 Paris CEDEX 16. 
TABLE OF CONTENTS

THE PRICE RESPONSIVENESS OF HOUSING SUPPLY IN OECD COUNTRIES ................................

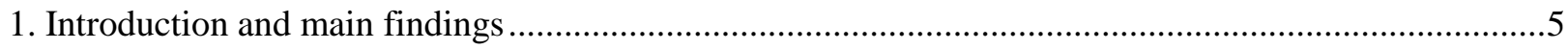

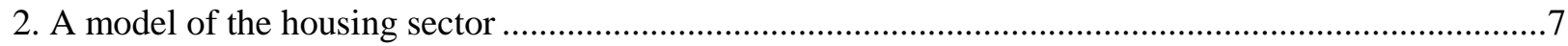

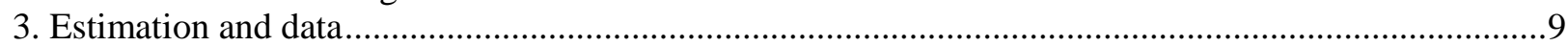

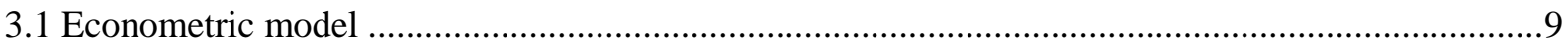

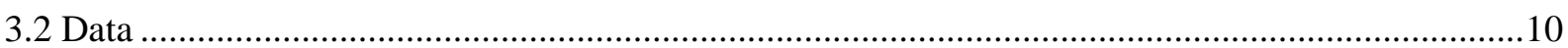

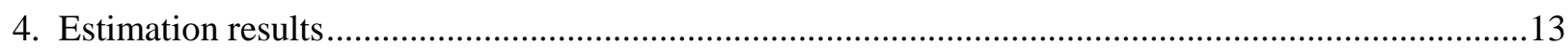

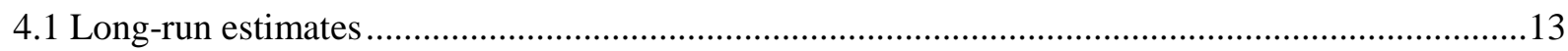

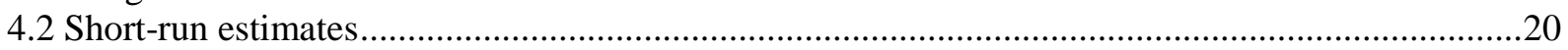

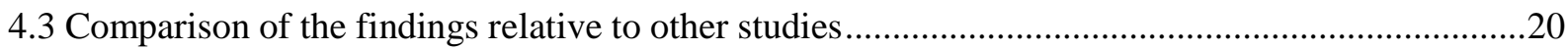

5. Factors influencing the responsiveness of housing supply to prices...................................................22

6. Economic and policy implications of the price responsiveness of housing supply ...............................25

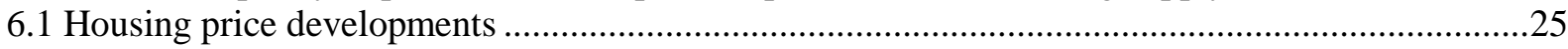

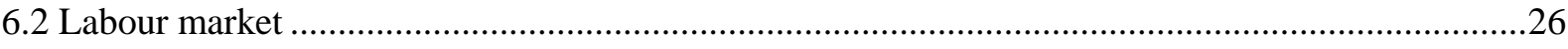

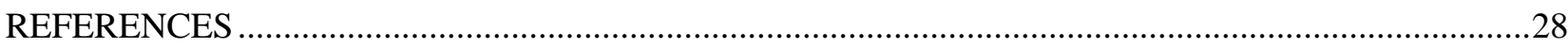

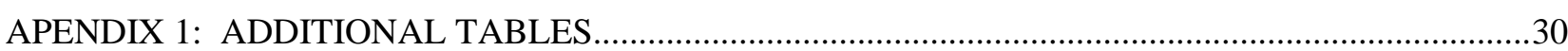

\section{Tables}

1. Demand equations by country: regression results................................................................................. 16

2. Supply equations by country: regression results.............................................................................18

3. Price responsiveness of housing supply and speed of supply response ..............................................21

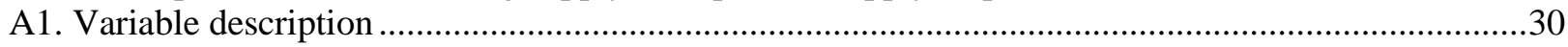

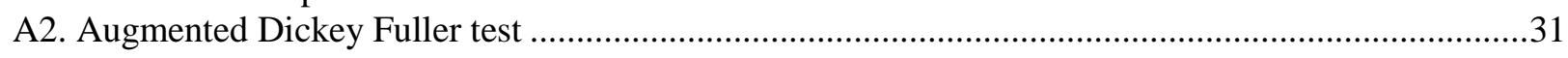

\section{Figures}

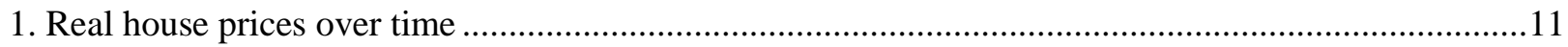

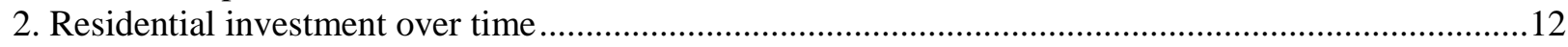

3. Price responsiveness of housing supply: selected OECD countries ..................................................14

4. Price responsiveness of supply and scarcity of land ...........................................................................23

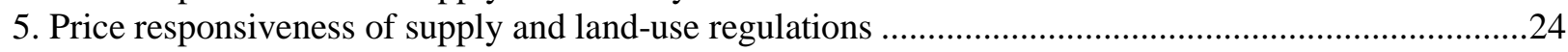


ECO/WKP(2011)6 
ECO/WKP(2011)6

\title{
THE PRICE RESPONSIVENESS OF HOUSING SUPPLY IN OECD COUNTRIES
}

\author{
By Aida Caldera Sánchez and Åsa Johansson ${ }^{1}$
}

\section{Introduction and main findings}

1. A crucial factor determining the functioning of housing markets is the responsiveness of housing supply to changes in prices. Differences in supply responsiveness to prices are important since they determine the extent to which the housing market responds to demand side shocks with more construction or higher prices, with potential implications for the evolution of housing prices and housing affordability. Indeed, existing evidence suggests that in supply-constrained markets, most of the adjustment occurs in the price of housing rather than in expanding housing supply (Glaser et al. 2008; Gyourko, 2009). Supply conditions also matter for house price volatility and aggregate economic stability. An unresponsive housing supply can increase the sensitivity of house prices to demand shocks and, thus, influence private consumption patterns and residential investment. For instance, in the short to medium term, an increase in housing demand will translate into lower increases in real house prices in areas with more responsive housing supply. However, the flip side is that in flexible-supply areas, housing investment adjusts more rapidly to large changes in demand contributing to more cyclical swings in economic growth, as witnessed by recent developments. A quantification of the responsiveness of housing supply with respect to prices can, therefore, shed light on the trend evolution and volatility of house prices in OECD countries and inform housing policy reforms aimed at dampening housing price volatility and, in interaction with macro policies, increase macroeconomic resilience to shocks.

2. Despite its importance for the analysis of housing markets and policy, very little cross-country empirical evidence exists on the responsiveness of supply with respect to prices, partly reflecting data constraints. This paper aims to fill this gap, by estimating the long-run price elasticity of new housing supply for 21 OECD countries for which data are available. The analysis is based on a stock-flow model of the housing market. Specifically, the approach chosen is to derive an empirical model to assess the functioning of the housing market, which is simple enough to involve reasonable data collection costs so that comparable estimates can be obtained for a large number of OECD countries and, yet, is grounded in theory. Building on the stock-flow model, the long-run price-elasticity of new housing supply is estimated separately for each country over the period from the early 1980s to mid-2000s, as the price coefficient on a long-run supply equation modelled as the flow of residential investment and jointly estimated with a long-

$1 \quad$ Corresponding authors are: Aida Caldera Sánchez (Aida.CalderaSanchez@oecd.org) and Åsa Johansson (Asa.Johansson@oecd.org) both at the OECD Economics Department. The authors would like to thank Virginia Alonso, Cristophe André, Dan Andrews, Jørgen Elmeskov, Giuseppe Nicoletti, Jean-Luc Schneider and Michael Skaarup for their valuable comments and Catherine Chapuis for excellent statistical work, as well as Irene Sinha for excellent editorial support. The views expressed in this paper are those of the authors and do not necessarily reflect those of the OECD or its member countries. 
run price equation in an error correction framework. ${ }^{2}$ Ample evidence suggests that housing markets only adjust slowly to changes in market conditions due to, among other factors, product heterogeneity and costly search and transaction costs. The error correction framework employed in the present paper takes into account this slow adjustment of housing markets.

3. Results suggest that housing responsiveness to price changes varies substantially across countries, with potential consequences for the speed of adjustment of housing markets. New housing supply tends to be relatively flexible in North America and some Nordic countries, while it is more rigid in continental European countries and in the United Kingdom. For instance, long-run supply elasticities in the United States, Canada, Sweden and Denmark are above unity, implying that in response to a demand shock, housing output will increase relatively more than prices. On the other hand, the responsiveness of housing supply tends to be quite low in countries like Switzerland (0.15), the Netherlands (0.19), Austria $(0.23)$ or Italy $(0.26)$. These estimates are broadly in line with the limited available evidence on the responsiveness of housing supply in OECD countries (e.g. Swank et al. 2002). Estimates of the speed of adjustment over the short term imply that between $20 \%$ and over $100 \%$ of the differences between actual and equilibrium investment are closed within a year depending on the country. The responsiveness of housing supply depends not only on national geographical and urban characteristics but also on policies, such as land use, planning and rental regulations. While the link is hard to establish empirically due to data limitations, we present some suggestive evidence that cumbersome land use and planning regulations are associated with a less responsive housing supply in the long-run across OECD countries.

4. These findings have implications for the understanding of the functioning of housing markets in OECD countries and the design of effective housing market policies. Evidence provided in Andrews (2010) shows that low responsiveness of housing supply has tended to exacerbate the price effect of changes in housing demand caused by financial, labour market or demographic shocks across OECD countries over the past decades. For example, in a country with supply elasticity half a standard deviation below the median OECD country, the increase in house prices linked to a demand shock was 50\% larger than if the elasticity were at the median. Thus in rigid supply environments, increases in housing demand are much more likely to be capitalised into house prices than to spur increases in the quantity of housing, at least over the horizon covered in this paper. Furthermore, there is also a negative association between housing supply responsiveness and real house price variability. In other words, house prices tend to rise faster in environments with less responsive housing supply, and the variability of house prices is also likely to be higher if the supply of housing is price-inelastic and if the demand for housing is subject to large shocks.

5. An unresponsive supply of housing has also implications for the functioning of labour markets and their adjustment to economic shocks. In the face of a major demand shock, an increase in labour demand may translate into less employment growth and higher wages in areas where it is relatively more difficult to build new housing in order to accommodate an inflow of workers. Existing evidence further suggests that in the face of region-specific shocks a constrained housing supply can lead to lower geographical mobility as households in lower-priced areas have a larger credit hurdle to clear if they wish to move to higher priced regions (Saks, 2008; Barker, 2004; Cameron and Muellbauer, 1998). Evidence provided in Caldera Sánchez and Andrews (2011) further shows that in countries with more responsive housing supply, residential mobility - particularly among younger households - tends to be much higher,

2 The analysis is macro in nature, essentially treating each country as a single housing market. Although in reality housing markets are typically local or regional, country level estimates give a sense of differences in the overall responsiveness of housing supply across countries. In the present paper, the supply of housing is modelled as the flow of residential investment rather than the stock of housing because of data limitations. This implies that the computed elasticity parameters can be interpreted as the elasticity of the flow of residential investment (or new supply) with respect to prices. 
and the same is true within cities in the United States. Econometric estimates suggest that increasing the elasticity of supply from the lowest to the average level in the OECD would raise the average household's mobility rate significantly.

6. The remainder of the paper is organised as follows. Section 2 presents the theoretical framework employed to analyse the housing sector. Sector 3, describes the approach to estimate the price-elasticity of new housing supply and the data used in the estimation. Section 4 presents the empirical results and compares the estimates of the responsiveness of housing supply with those of other studies. Section 5 discusses potential drivers of differences in the responsiveness of housing supply across countries, while the final section discusses economic implications for the functioning of housing and labour markets, in light of the findings in this paper and policy reforms to enhance the responsiveness of housing supply.

\section{A model of the housing sector}

7. This section presents the conceptual framework underlying the estimation of the long-run price elasticity of new housing supply. The empirical approach builds on a stock-flow model of the housing sector to estimate the elasticity of new housing supply with respect to price. This model has long been used in the literature as the main theoretical framework to describe the housing sector (see Di Pasquale and Wheaton (1994) for a review). It has the key advantage of considering the dual role of housing as a capital investment and consumption good, as well as to distinguish between the stock of housing and the flow of housing investment. One important feature of the housing market is that the housing stock adjusts slowly to changes in demand: housing investment is lumpy as building takes time and depreciation of the housing stock is slow. Thus, housing markets can clear rapidly only if prices react strongly to tensions between demand and supply. However, the heterogeneity of housing generates search and transaction costs which make it difficult for households to react swiftly to price signals (DiPasquale and Wheaton, 1994). Hence, stock equilibrium is achieved only in the long-run.

8. In the long-run, two important drivers will influence housing demand (Meen, 2002). First, expected or permanent income and developments in the age and structure of the population will determine the quantity of housing demanded. Second, the user cost of holding the housing asset, which is in turn influenced by interest rates, taxation and expected capital gains of owning the house also matters for demand. Housing demand can be expressed as a function of exogenous factors such as, income, demographic characteristics and the user cost of housing (summarised in $\mathrm{X}_{1}$ ), and the real price level of housing (P). In the long run, the demand for housing (D) determines the equilibrium price that will clear the stock of housing (S), as given by the following equation:

$$
D\left(X_{1}, P\right)=S=\int_{0}^{T} d S
$$

9. On the supply side, the stock of housing slowly depreciates over time, at a depreciation rate $\partial$, and expands gradually with new residential investment (I) as given by the differential equation (2):

$$
d S=I\left(X_{2}, P\right)-\partial S
$$

The stock equilibrium demand, given by equation (1) leads to long-run adjustments in the rate of growth of the housing stock through investment in new construction. Residential investment is, in turn, a function of cost shifters, such as costs of production in terms of land, labour and materials, and housing policies summarised in the vector $\mathrm{X}_{2}$, as well as real house prices. Because house prices affect the incentives to build new housing and/or maintain the existing stock of housing they have an effect on residential investment. 
10. Inverting the demand function (1) (assuming a log-linear relationship between the variables) and adding an error term $\varepsilon_{\mathrm{t}}^{\mathrm{p}}$, the observed price, $\mathrm{p}_{\mathrm{t}}$ can be expressed as a function of the equilibrium price $p^{*}{ }_{t}$ (determined by the housing stock and demand shifters):

$$
p_{t}=\alpha_{0}-\alpha_{1} s_{t}+\alpha^{\prime}{ }_{3} X_{1}+\varepsilon^{p}{ }_{t}=p^{*}{ }_{t}+\varepsilon^{p}{ }_{t}
$$

where all the variables are expressed in logs (and denoted in small letters) and the subscript $t$ denotes time. Similarly, long-run residential investment can be expressed as follows, where the coefficient $\beta_{1}$ denotes the long-run elasticity of investment with respect to prices: ${ }^{3}$

$$
i_{t}=\beta_{0}+\beta_{1} p_{t}+\beta_{2}^{\prime} X_{2}+\varepsilon^{i}{ }_{t}=i_{t}^{*}+\varepsilon^{i}{ }_{t}
$$

11. Taking into account the slow adjustment of housing markets the model further incorporates an error correction process in both the demand and supply sides. Ample evidence suggests that the housing market adjusts gradually to shocks due to, among other factors, transaction costs (e.g. Di Pasquale and Wheaton, 1994; Mayer and Somerville, 2000). For instance, Di Pasquale and Wheaton (1994) suggest that product heterogeneity and costly search imply that the anticipated sale time for a house can be long and exhibit significant variance leading to a slow clearing of the housing market. Specifically, if the housing market is in equilibrium and a shock occurs, this creates a disequilibrium causing a wedge between the equilibrium price and the actual price level $\left(\mathrm{p}_{\mathrm{t}}-\mathrm{p}_{\mathrm{t}}{ }^{*}\right)$ due to such rigidities. For instance, if the desired level of the housing stock is higher than the existing supply, a negative wedge will appear between the actual price of housing and the equilibrium price, and actual house prices will gradually rise spurring new residential investment until the equilibrium levels are reached.

12. The following short run demand equation summarises the dynamics of house prices and their reaction to housing market imbalances:

$$
\Delta p_{t}=\phi_{0}+\phi_{1} \varepsilon^{p}{ }_{t-1}+\phi_{2}^{\prime} \Delta X_{1}+u_{t}^{p}
$$

where $\Delta$ denotes the first difference of a variable and $\varepsilon_{\mathrm{t}}^{\mathrm{p}}$ captures the disequilibrium between actual and equilibrium house price. The speed of price adjustment to equilibrium is captured by $\phi_{1}$ and is expected to be negative reflecting the convergence between actual prices and equilibrium prices over time. Additionally, changes in house prices are a function of changes in other factors such as household income or the user cost, summarised in $\mathrm{X}_{1}$ and $\mathrm{u}_{\mathrm{t}}^{\mathrm{p}}$ is an error term.

13. The dynamics of residential investment are, in turn, described by the following equation, where the error correction term $\varepsilon_{t}^{i}$ tracks the level of over or under investment.

$$
\Delta i_{t}=\delta_{0}+\delta_{1} \varepsilon^{i}{ }_{t-1}+\delta^{\prime}{ }_{2} \Delta X_{2}+u_{t}^{i}
$$

14. Equation (6) indicates that a fraction $\delta_{1}$ of the deviations in investment from equilibrium are corrected over the following period, at a speed of adjustment $\delta_{1}$ (with $\delta_{1}<0$ to ensure convergence). The with respect to prices. The elasticity of the stock of housing with respect to prices would then be (following equation (2)) $\beta_{1}$ divided by the depreciation rate $(\partial)$ of the housing stock. 
vector $\mathrm{X}_{2}$ in turn captures factors which influence changes in residential investment, such as variations in the costs of construction and $\mathrm{u}_{\mathrm{t}}^{\mathrm{i}}$ is an error term.

\section{Estimation and data}

\subsection{Econometric model}

15. Building on the theoretical framework outlined above and on earlier OECD work (Hüfner and Lundsgaard, 2007; Rae and van den Noord, 2006), the following long-run price and investment equations are estimated in an error correction framework employing the Engle-Granger two-step estimation procedure (1987). ${ }^{4}$ In order to obtain an estimate of the long-run price-elasticity of new housing supply for each country, the following system of equations is estimated separately for each of the OECD countries using quarterly data:

$$
\begin{aligned}
& p_{t}=\alpha_{0}+\alpha_{1} y_{t}+\alpha_{2} R_{t}+\alpha_{3} s_{t}+\alpha_{4} d_{t}+\gamma_{t}+E C T^{p}{ }_{t} \\
& i_{t}=\beta_{0}+\beta_{1} p_{t-1}+\beta_{2} C C_{t-1}+\beta_{3} d_{t}+\gamma_{t}+E C T^{i}{ }_{t}
\end{aligned}
$$

The dependent variable in the demand equation is real house prices, $\mathrm{p}_{\mathrm{t}}$, while the dependent variable in the supply equation is real gross residential investment, $i_{t}$. The coefficient of interest in these equations is $\beta_{1}$, which measures the long-run elasticity of housing investment, or new housing supply, with respect to prices. As a robustness check the investment equations were also estimated separately from the price equation. The resulting elasticity estimates and the country ranking in terms of responsiveness are in line with system results. The system approach is preferred as it allows for feedback between supply and demand and is a more efficient estimation approach.

16. The explanatory variables in the price equation include real income $\left(\mathrm{y}_{\mathrm{t}}\right)$, the real interest rate $\left(\mathrm{R}_{\mathrm{t}}\right)$, the stock of residential dwellings $\left(s_{t}\right)$, and a demographic variable $\left(d_{t}\right)$ capturing the share of the age cohort 25-44 in population, i.e. those who are more likely to buy housing. The real interest rate is a simple measure of the user cost, which measures the opportunity cost of capital tied up in the property or taken on credit. $^{5}$ The coefficients on the stock of housing and interest rates are expected to be negative, while the coefficient on income and demographics are expected to be positive. The explanatory variables in the investment equation include real residential construction costs $\left(\mathrm{cc}_{\mathrm{t}-1}\right)$, real house prices $\left(p_{t-1}\right)$ and the same demographic variables included in the first equation $\left(d_{t}\right)$, as the size and structure of the population is expected to influence the incentives to build. The coefficients on construction costs are expected to be negative, while the coefficients on prices and the demographic variable are expected to be positive. All the variables are in logs, except the real interest rate. Both construction costs and real house prices enter lagged in the equation to reflect the nature of the construction industry, where there is typically a lag between price signals and investment in housing, and to avoid potential endogeneity. In addition, both equations include a set of quarterly dummies $\gamma_{t}$ to control for seasonal effects.

$4 \quad$ In their seminal paper on co-integration, Engle and Granger (1987) suggest a two-step analysis to test for co-integration: estimate the co-integrating regression by ordinary least squares (OLS) in the first step and then test for a unit root in the residuals from the co-integrating regression in the second step. If the null of a unit root in the residuals is rejected, then there is evidence of co-integration and the residual from the first step regression can be added as the error correction term in the dynamic regression.

5 A broader measure of the user cost also takes into account differences in housing taxes, depreciation and any anticipated capital gains from owning the house. As housing taxes and depreciation usually show high inertia, the real interest rate is one of the main components shaping the user-cost. 
17. The estimated residuals $E C T^{p}{ }_{t}$ and $E C T^{i}{ }_{t}$ are then included as error correction terms, in the following equations explaining the short-term evolution of prices and investment:

$$
\begin{aligned}
& \Delta p_{t}=\phi_{0}+\phi_{1} \Delta y_{t}+\phi_{2} \Delta R_{t}+\phi_{3} \Delta s_{t}+\phi_{4} \Delta d_{t}+\phi_{5} E C T^{p}{ }_{t-1}+\gamma_{t}+\varepsilon_{t} \\
& \Delta i_{t}=\delta_{0}+\delta_{1} \Delta c c_{t-1}+\delta_{2} \Delta p_{t-1}+\delta_{3} \Delta d_{t}+\delta_{4} E C T^{i}{ }_{t-1}+\gamma_{t}+v_{t}
\end{aligned}
$$

where $\mathrm{ECT}_{\mathrm{t}-1}$ is the error-correction term, i.e. the residual from the long-run equation, lagged one period. The coefficients $\phi_{5}$ and $\delta_{4}$ measure the (quarterly) speed of adjustment to the long term equilibrium. The parameter $\phi_{5}$ is expected to be negative, as disequilibrium in prices in previous periods will adjust back to equilibrium over the next periods. Similarly the speed of adjustment in investment $\left(\delta_{4}\right)$ is expected to be negative as disequilibrium in investment in the previous period should have a positive effect on investment in the next period; that is if the actual flow of housing investment is lower than what is predicted by fundamentals, investment will rise.

18. Both systems of equations, the long-run relationships given by equations (7) and (8) and the short-run relationships given by equations (9) and (10), are jointly estimated using seemingly unrelated regressions (SUR), to account for heteroskedasticity and contemporaneous serial correlations in the error terms across equations.

\subsection{Data}

19. The estimation period differs across countries depending on data availability; however, the typical timeframe is from the 1980s to the mid-/late-2000s. Data definitions and sources are as follows. Real prices are inflation-adjusted nominal prices sourced from the OECD or from national data sources. The measure of housing supply is real residential investment, more precisely defined as gross fixed capital formation in the housing sector expressed in volume indices, sourced from the OECD. The stock of housing is the total number of dwellings in a given country sourced from the United Nations Economic Commission for Europe (UNECE). The other variables involved in the estimation include, real income, interest rates, population and construction costs and are sourced from different OECD databases. Income is measured by either GDP per capita, deflated by the national GDP deflator, or by real household disposable income, depending on data availability. Interest rates are measured by the long term or short term real interest rate (to the extent households are short-sighted; the short-term interest rate can influence their decision to buy a house), depending on the predominant type of mortgage loan interest readjustment in each country. Population is measured by the share of the 25-44 years old cohort in total population, or the total national population in that age cohort depending on which variable gives the best model fit. A detailed description of the variables and their sources is provided in Table A1 in the Appendix.

20. Figure 1 plots the evolution of real house prices over the sample period for the OECD countries included in the analysis. Real house prices rose strongly in a majority of OECD countries since the mid1980s. In several countries, prices have increased by more than $90 \%$ since the early 1980s (e.g. Ireland, Spain, the United Kingdom, the Netherlands, Belgium etc.). However, in a few countries real house prices remained stable or even decreased (e.g. Japan, Switzerland and Germany etc.). 
Figure 1: Real house prices over time

Nominal prices deflated by the consumer price index, index, $2000=100$
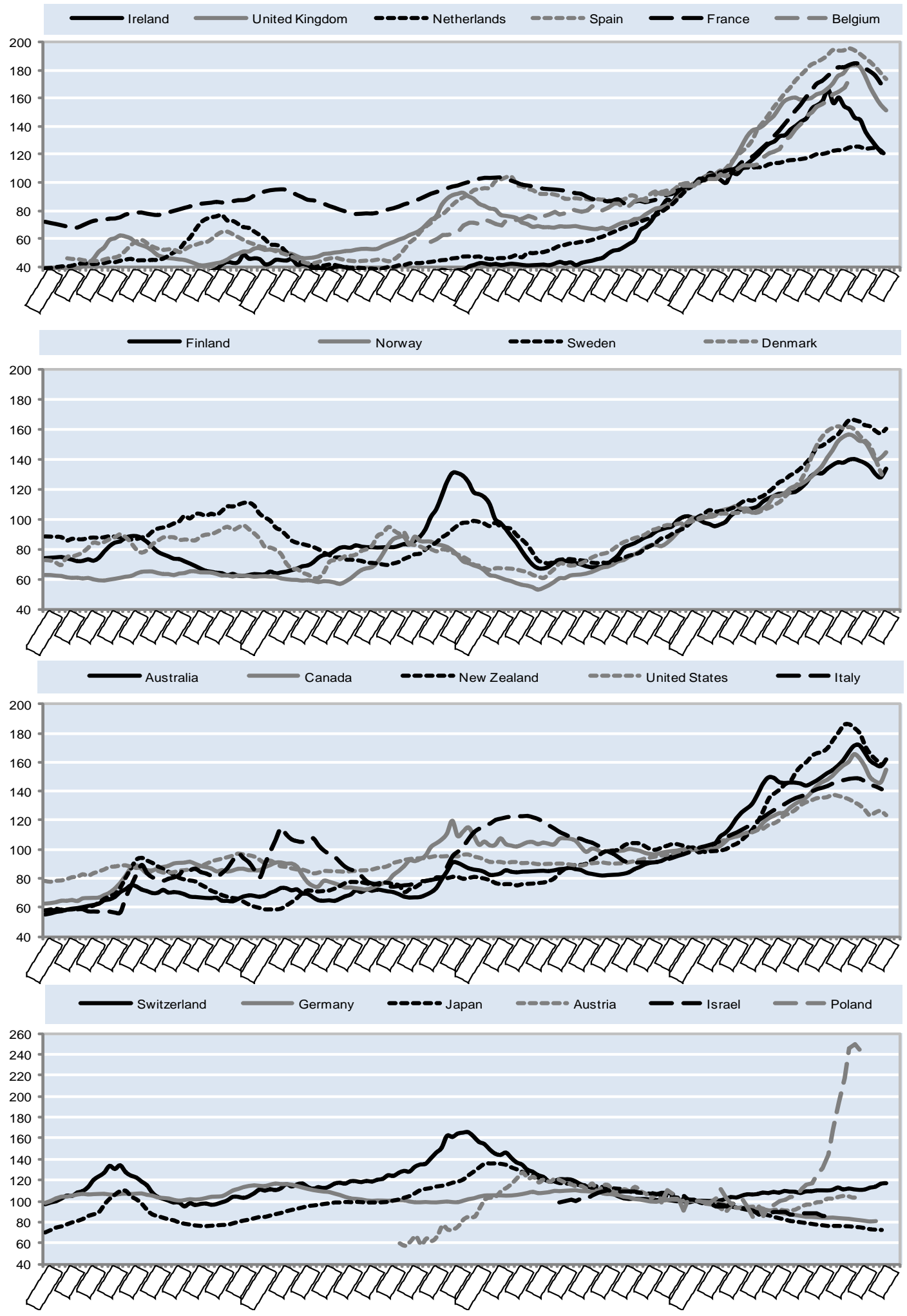

Sources: National sources and OECD Economic Outlook No. 87. 
Figure 2: Residential investment over time
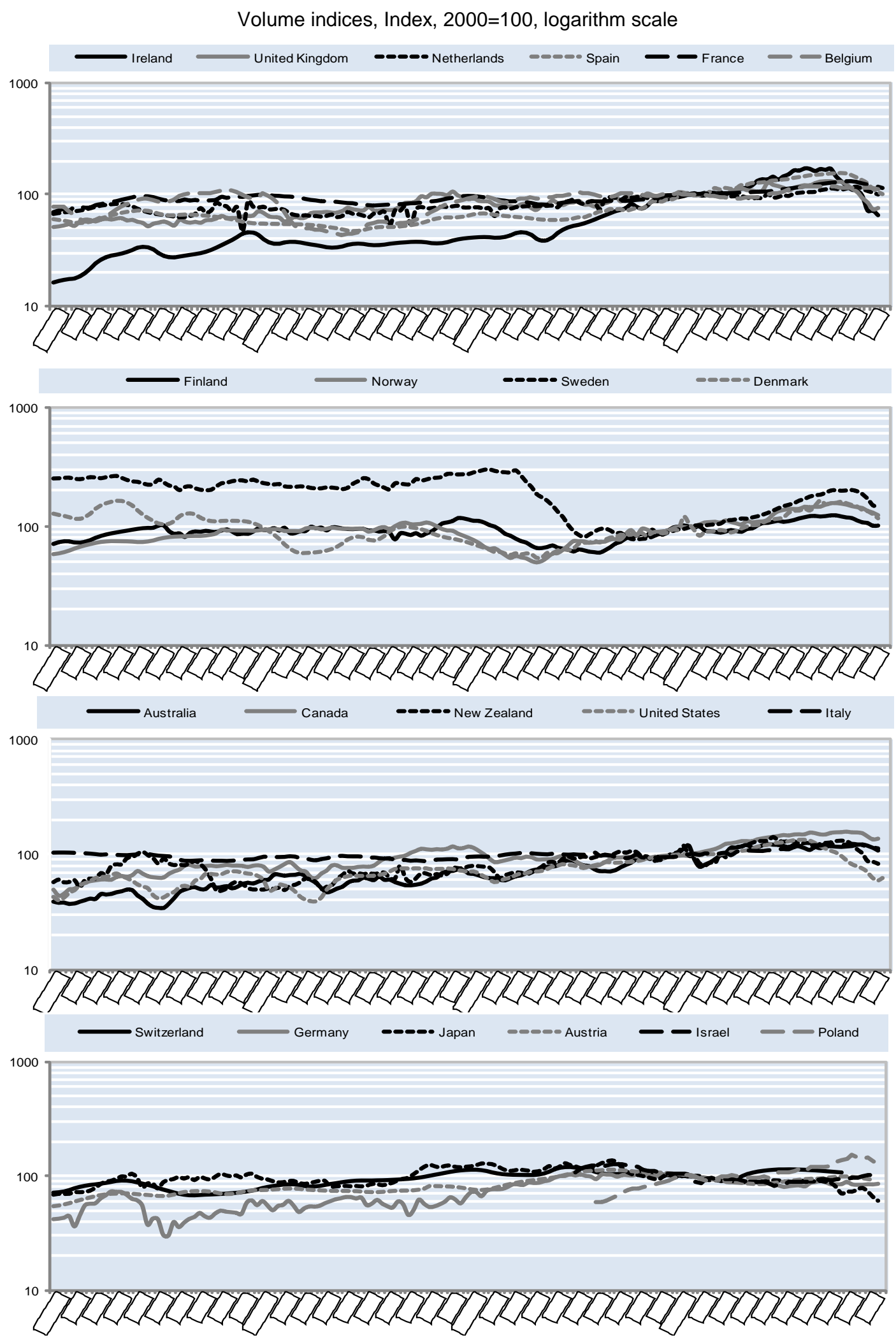

Source: OECD Economic Outlook No. 87. 
21. On the other hand, the increase in real house prices was accompanied by increased housing investment in several countries. Figure 2 plots the real value of residential investment, which comprises major additions and renovations as well as new units, for the countries for which data are available. From the mid-1990s until 2006 investment grew rapidly in Spain, Ireland and the Nordic countries, while it was stagnant or even declining in Germany, Switzerland, Japan and Austria. Despite the fact that the data used in the analysis do not allow to distinguish between the different components of residential investment, other sources indicate that in all countries new construction tends to constitute the largest share of housing investment $-80 \%$ on average in 2004 in countries for which data are available (Bulletin Housing). Only in Sweden, the United Kingdom and Poland does maintenance and repairs of existing dwellings account for at least 30\% of investment, possibly reflecting a relatively old stock of housing in these countries.

\section{Estimation results}

22. Tables 1 and 2 below report the estimation results for the 21 OECD countries, for which the data are available, showing the results for the long-run and short-run price and investment relationships respectively. Panel A summarises the results for the long-run relationships, while Panel B summarises the estimates for short-run dynamics.

23. As a first step in the estimation, the order of integration of the series involved in the estimation of the long-run relationship is verified using the standard Augmented Dickey Fuller (ADF) test for the presence of unit roots. The tests include a constant, thus assuming that the overall mean is not zero, and a deterministic trend, and the optimal lag length was chosen based on the Modified Akaike Information Criterion (MAIC) of Ng and Perron (2001). The results reported in the Appendix Table A2 provide evidence that, with a few exceptions ${ }^{6}$, the long run relationships are integrated of order one. Alternative Dickey-Fuller GLS tests, with higher power and better overall performance in terms of sample size than the standard ADF, yielded similar results. Then, the existence of a long-run relationship between real house prices or investment and the explanatory variables in equations (7) and (8) is verified including the error correction terms derived from the long-run relationship into the dynamic regressions (9) and (10). The error correction terms all have a negative sign and are statistically significant, suggesting that equations (7) and (8) can indeed be interpreted as long-run relationships. ${ }^{7}$

\subsection{Long-run estimates}

24. Panels A of Tables 1 and 2 give the estimates for the long-run price and investment equation. Most of the demand and supply explanatory variables have coefficients that are significant and consistent with priors. In the price equation (Table 1), income and the variable capturing the structure of the population have, as expected, a positive effect on prices, while the stock of housing and interests rates have a negative effect. ${ }^{8}$ House prices tend to increase with households' disposable income and population as

$6 \quad$ The only exception are that the population and price series tend to be stationary in levels for Italy, Spain and the United Kingdom, and investment is stationary in levels for Australia and United States.

7 In the standard Engle Granger approach the existence of a co-integration relationship between the series would be tested by verifying the stationarity of the residuals from the long-run relationships. In this set-up the long-run relationships are, however, estimated employing seemingly unrelated regressions (SUR) rather than OLS, so the standard ADF tests of the residuals are not valid. Visual inspection of the residuals of the long-run relationships, however, suggests that the series of residuals are stationary. The alternative test based on the significance of the error correction term in the short-run equation is, therefore, used (see Banarjee et al. 1993).

The stock of housing is, however, positive and significant in 2/20 specifications (i.e. Spain and Denmark). A possible reason for this counterintuitive result is that the stock of housing is picking up the effect of population on house prices, which is not included in the equation as population is highly correlated with the dwelling stock. As a robustness check, including population divided by the dwelling stock, gives a 
income and population growth generates higher demand for housing. As the coefficients in Table 1 indeed show, in the long-run, the elasticity of real house prices with respect to real income are close to or above unity in most countries.

25. Turning to the effect of the housing stock and real interest rates, they have a dampening effect on house prices. The housing stock tends to have a positive and significant effect on prices, in line with the theoretical prediction that increases in the stock of housing, and thus larger supply, lead to lower prices in the long-run. The small effect of interest rates on prices is in line with previous evidence suggesting that declining interest rates have had a modest impact on real house prices after controlling for other demand and supply factors (See Andrews et al., 2011). In the supply equation (Table 2), lagged prices and the demographic variable have a positive effect on investment while construction costs have a negative effect. Real construction costs have, however, a positive and significant effect on investment in Belgium, Germany and the United Kingdom, which could be accounted for poor quality data on construction costs.

26. Figure 3 plots the coefficient on lagged prices in the long-run investment equation, i.e. the priceelasticity of new housing supply which captures the responsiveness of new supply to changes in prices. There are remarkable differences in the responsiveness of new housing supply across countries. In some countries new housing supply appears to be quite responsive to prices. Supply elasticities in Sweden, the United States, Denmark, Canada, Japan and Finland are at or above unity implying that in response to a demand shock housing output will increase proportionally more than prices. On the other hand, there are several countries with particularly low elasticities of supply, including Switzerland, the Netherlands, Austria and Italy. Housing supply is particularly unresponsive to prices in Switzerland relative to other countries, about three times less responsive than in countries like France or Germany, and more than ten times less responsive than in the United States and Sweden where supply is the most responsive among the countries in the sample. These estimates are in line with the scarce cross-country evidence available, which is discussed in detail in the next section.

\section{Figure 3. Price responsiveness of housing supply: selected countries ${ }^{1}$}

Estimates of the long-run price-elasticity of new housing supply

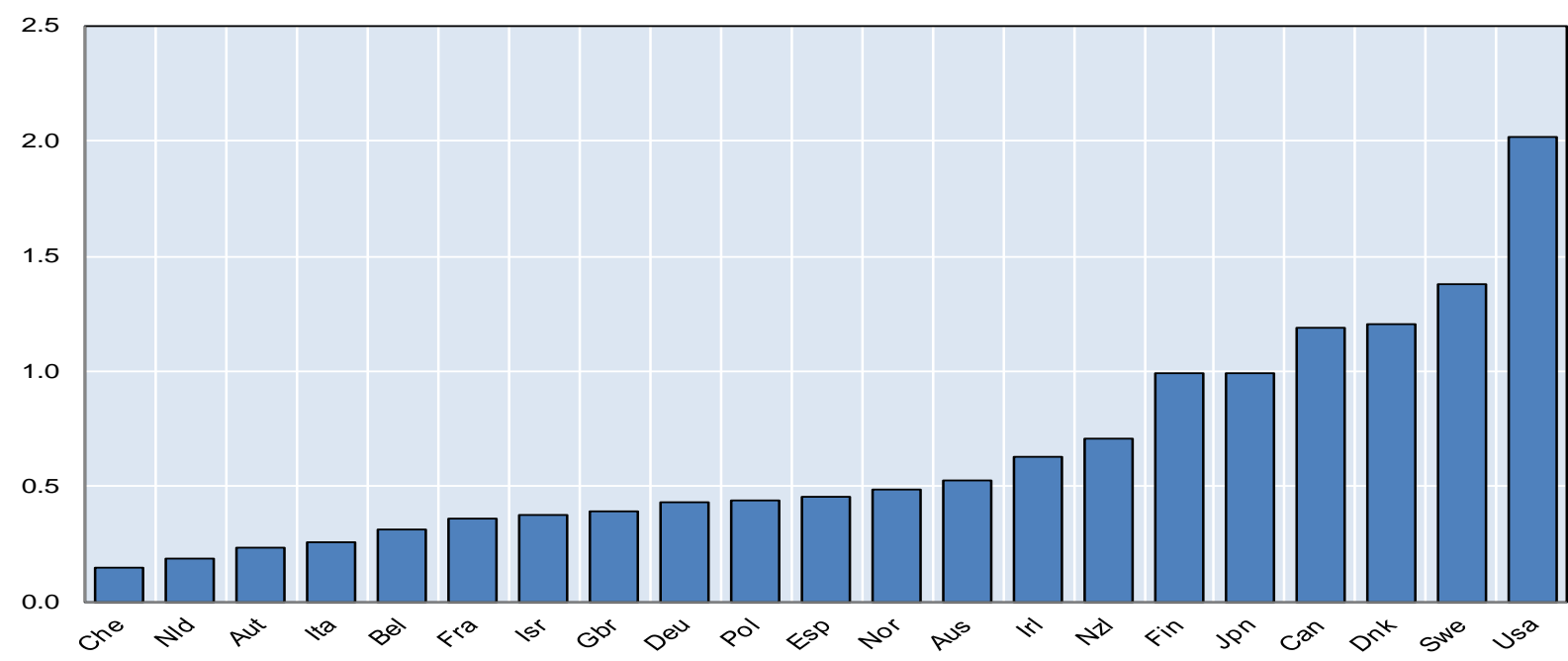

1. Estimates of the long-run price elasticity of new housing supply where new supply is measured by residential investments (i.e. the coefficient on lagged prices in the long-run investment equation as reported in Table 1). All elasticities are significant at least at the $10 \%$ level. The estimation period is from early 1980s to mid-2000s. In the case of Spain, restricting the sample to the period 19952007, which would reflect recent developments in housing markets (such as the large stock of unsold houses resulting from the

negative and significant coefficient for Spain and non significant for Denmark, while the long-run price elasticities of new housing supply are close to the baseline results 
ECO/WKP(2011)6

construction boom starting in 2000 and peaking in 2007-09), only slightly increases the estimate of the elasticity of housing supply from 0.45 to 0.58 .

Source: OECD estimates. 
Table 1. Demand equations by country: regression results ${ }^{1}$

A.: Long run house price relationships by country

\begin{tabular}{|c|c|c|c|c|c|c|c|c|c|c|c|}
\hline \multicolumn{12}{|c|}{ Dependent variable: log real house prices } \\
\hline & Australia $^{2}$ & Austria $^{3}$ & Belgium & Canada & Denmark & Finland & France & Germany & Ireland & Israel & Italy \\
\hline Income t & $\begin{array}{c}1.942 \\
(0.208)^{\star \star \star *}\end{array}$ & $\begin{array}{c}1.104 \\
(0.386)^{\star \star \star}\end{array}$ & $\begin{array}{c}1.613 \\
(0.129)^{\star \star \star \star ~}\end{array}$ & $\begin{array}{c}1.531 \\
(0.224)^{\star \star \star *}\end{array}$ & $\begin{array}{c}2.905 \\
(0.629)^{\star \star \star}\end{array}$ & $\begin{array}{c}1.634 \\
(0.207)^{\star \star \star *}\end{array}$ & $\begin{array}{c}4.355 \\
(0.374)^{\star \star \star \star}\end{array}$ & $\begin{array}{c}0.663 \\
(0.152)^{\star \star \star}\end{array}$ & $\begin{array}{c}0.615 \\
(0.078)^{\star \star \star \star ~}\end{array}$ & $\begin{array}{c}0.798 \\
(0.173)^{\star \star \star}\end{array}$ & $\begin{array}{c}1.762 \\
(0.511)^{\star \star \star \star}\end{array}$ \\
\hline Dw elling stock $t$ & $\begin{array}{c}-9.093 \\
(0.738)^{\star \star \star}\end{array}$ & $\begin{array}{c}-2.050 \\
(0.309)^{\star \star \star}\end{array}$ & $\begin{array}{c}-2.199 \\
(0.329)^{\star \star \star}\end{array}$ & $\begin{array}{c}-1.093 \\
(0.249)^{\star \star \star}\end{array}$ & $\begin{array}{c}1.811 \\
(0.784)^{\star *}\end{array}$ & $\begin{array}{c}-14.928 \\
(2.394)^{\star \star \star}\end{array}$ & $\begin{array}{c}-7.332 \\
(0.760)^{\star \star \star}\end{array}$ & $\begin{array}{c}-1.367 \\
(0.198)^{\star \star \star}\end{array}$ & $\begin{array}{l}-0.739 \\
(0.447)\end{array}$ & $\begin{array}{c}-0.415 \\
(0.167)^{\star *}\end{array}$ & $\begin{array}{c}-2.906 \\
(0.491)^{\star \star \star}\end{array}$ \\
\hline Interest rate $\mathrm{t}$ & $\begin{array}{l}-0.000 \\
(0.003)\end{array}$ & $\begin{array}{l}-0.005 \\
(0.008)\end{array}$ & $\begin{array}{c}0.001 \\
(0.002)\end{array}$ & $\begin{array}{l}-0.005 \\
(0.004)\end{array}$ & $\begin{array}{c}-0.013 \\
(0.005)^{\star \star \star}\end{array}$ & $\begin{array}{l}-0.001 \\
(0.003)\end{array}$ & $\begin{array}{c}-0.012 \\
(0.007)^{\star}\end{array}$ & $\begin{array}{c}0.004 \\
(0.002)^{\star *}\end{array}$ & $\begin{array}{c}-0.014 \\
(0.003)^{\star \star \star \star}\end{array}$ & $\begin{array}{l}-0.003 \\
(0.004)\end{array}$ & $\begin{array}{c}-0.009 \\
(0.005)^{*}\end{array}$ \\
\hline Population $\mathrm{t}$ & $\begin{array}{c}13.510 \\
(1.114)^{\star \star \star *}\end{array}$ & $\begin{array}{c}2.669 \\
(1.920)\end{array}$ & $\begin{array}{c}16.233 \\
(0.836)^{\star \star \star *}\end{array}$ & $\begin{array}{c}0.700 \\
(0.171)^{\star \star \star}\end{array}$ & .. & $\begin{array}{l}-1.208 \\
(1.783)\end{array}$ & $\begin{array}{c}3.488 \\
(1.341)^{\star \star \star \star}\end{array}$ & $\begin{array}{c}1.076 \\
(0.148)^{\star \star \star}\end{array}$ & $\begin{array}{c}6.366 \\
(1.422)^{\star \star \star}\end{array}$ & $\begin{array}{l}-0.074 \\
(0.121)\end{array}$ & .. \\
\hline Constant & $\begin{array}{c}-80.875 \\
(4.606)^{\star \star \star}\end{array}$ & $\begin{array}{l}-13.534 \\
(6.544)^{\star \star}\end{array}$ & $\begin{array}{l}-154.667 \\
(5.433)^{\star \star \star \star}\end{array}$ & $\begin{array}{c}-33.107 \\
(4.143)^{\star \star \star}\end{array}$ & $\begin{array}{c}18.291 \\
(11.994)\end{array}$ & $\begin{array}{c}-225.570 \\
(93.819)^{\star \star}\end{array}$ & $\begin{array}{l}-40.848 \\
(3.315)^{\star \star \star}\end{array}$ & $\begin{array}{l}-2.768 \\
(1.526)\end{array}$ & $\begin{array}{l}-53.291 \\
(8.915)^{\star \star \star}\end{array}$ & $\begin{array}{c}0.213 \\
(3.322)\end{array}$ & $\begin{array}{c}5.301 \\
(10.552)\end{array}$ \\
\hline Number of observations & 109 & 69 & 93 & 101 & 109 & 69 & 89 & 151 & 109 & 48 & 53 \\
\hline \multicolumn{12}{|c|}{ B. Short run house price relationships by country } \\
\hline \multicolumn{12}{|c|}{ Dependent variable: 1 st difference log real house prices } \\
\hline & Australia $^{2}$ & Austria $^{3}$ & Belgium & Canada & Denmark & Finland & France & Germany & Ireland & Israel & Italy \\
\hline$\Delta$ Income t & $\begin{array}{c}0.550 \\
(0.240)^{\star \star}\end{array}$ & $\begin{array}{l}-0.131 \\
-0.896\end{array}$ & $\begin{array}{c}0.736 \\
(0.338)^{\star \star}\end{array}$ & $\begin{array}{c}0.364 \\
(0.208)^{*}\end{array}$ & $\begin{array}{c}0.074 \\
(0.241)\end{array}$ & $\begin{array}{c}0.285 \\
(0.250)\end{array}$ & $\begin{array}{c}0.280 \\
(0.226)\end{array}$ & $\begin{array}{c}0.232 \\
(0.071)^{\star \star \star}\end{array}$ & $\begin{array}{c}1.025 \\
(0.228)^{\star \star \star \star}\end{array}$ & $\begin{array}{c}0.859 \\
(0.493)^{*}\end{array}$ & $\begin{array}{c}0.261 \\
(0.377)\end{array}$ \\
\hline$\Delta$ Dw elling stock $t$ & $\begin{array}{c}-8.882 \\
(1.637)^{\star \star \star}\end{array}$ & $\begin{array}{c}-1.494 \\
(0.551)^{\star \star \star *}\end{array}$ & $\begin{array}{c}0.183 \\
(0.642)\end{array}$ & $\begin{array}{c}0.342 \\
(0.798)\end{array}$ & $\begin{array}{c}0.204 \\
(0.398)\end{array}$ & $\begin{array}{l}-2.002 \\
(4.549)\end{array}$ & $\begin{array}{l}-0.360 \\
(1.370)\end{array}$ & $\begin{array}{c}0.665 \\
(0.394)^{*}\end{array}$ & $\begin{array}{c}0.436 \\
(0.416)\end{array}$ & $\begin{array}{c}0.137 \\
(0.565)\end{array}$ & $\begin{array}{l}-0.959 \\
(0.859)\end{array}$ \\
\hline$\Delta$ Population $\mathrm{t}$ & $\begin{array}{c}9.276 \\
(4.077)^{\star \star}\end{array}$ & $\begin{array}{l}-0.924 \\
(8.125)\end{array}$ & $\begin{array}{c}17.278 \\
(4.870)^{\star \star \star \star}\end{array}$ & $\begin{array}{l}-0.166 \\
(0.663)\end{array}$ & & $\begin{array}{c}8.180 \\
(2.932)^{\star \star \star}\end{array}$ & $\begin{array}{c}0.993 \\
(2.667)\end{array}$ & $\begin{array}{c}1.036 \\
(0.203)^{\star \star \star}\end{array}$ & $\begin{array}{c}2.720 \\
(2.019)\end{array}$ & $\begin{array}{c}2.875 \\
(5.569)\end{array}$ & $\begin{array}{l}. . \\
. .\end{array}$ \\
\hline ECT t-1 & $\begin{array}{c}-0.058 \\
(0.029)^{\star *}\end{array}$ & $\begin{array}{c}-0.299 \\
(0.078)^{\star \star \star}\end{array}$ & $\begin{array}{c}-0.110 \\
(0.052)^{\star *}\end{array}$ & $\begin{array}{c}-0.054 \\
(0.029)^{*}\end{array}$ & $\begin{array}{l}-0.027 \\
(0.015)^{*}\end{array}$ & $\begin{array}{c}-0.130 \\
(0.048)^{\star \star \star * ~}\end{array}$ & $\begin{array}{c}-0.054 \\
(0.027)^{*}\end{array}$ & $\begin{array}{c}-0.035 \\
(0.013)^{\star \star \star}\end{array}$ & $\begin{array}{c}-0.071 \\
(0.029)^{* *}\end{array}$ & $\begin{array}{c}0.017 \\
(0.031)\end{array}$ & $\begin{array}{c}-0.050 \\
(0.027)^{*}\end{array}$ \\
\hline Number of observations & 108 & 68 & 92 & 100 & 108 & 68 & 88 & 150 & 108 & 42 & 52 \\
\hline
\end{tabular}

1. Results from the long-run and short-run price relationships, estimated jointly with the investment equations, employing a seemingly unrelated regression (SUR) model. All the specifications include a full set of quarterly dummies. Standard errors are reported in parentheses. ${ }^{* \star}$, ${ }^{* *}$, * denote significance at the $1 \%, 5 \%$ and $10 \%$.

2. The stock is lagged 1 year.

3. The model for Austria includes, in addition to the current stock, the stock lagged 1 year because the fit of the model is superior. The coefficients for the 1 year lag are significant at

the $1 \%$ but are not reported for brevity

Source: OECD estimates. 
Table 1. Demand equations by country: regression results ${ }^{1}$ (cont'd)

A.: Long run house price relationships by country

\begin{tabular}{|c|c|c|c|c|c|c|c|c|c|c|}
\hline \multicolumn{11}{|c|}{ Dependent variable: log real house prices } \\
\hline & Japan & Netherlands & New Zealand & Norw ay & Poland & Spain & Sweden & Sw itzerland & United Kingdom & United States \\
\hline Income t & $\begin{array}{l}2.015 \\
(0.116)^{\star \star \star}\end{array}$ & $\begin{array}{l}2.516 \\
(0.298)^{\star \star \star}\end{array}$ & $\begin{array}{l}0.982 \\
(0.498)^{\star \star}\end{array}$ & $\begin{array}{l}1.191 \\
(0.067)^{\star \star \star}\end{array}$ & $\begin{array}{l}3.483 \\
(0.679)^{\star \star \star}\end{array}$ & $\begin{array}{l}1.600 \\
(0.148)^{\star \star \star}\end{array}$ & $\begin{array}{l}2.825 \\
(0.168)^{\star \star \star \star}\end{array}$ & $\begin{array}{l}3.289 \\
(0.268)^{\star \star \star}\end{array}$ & $\begin{array}{l}3.585 \\
(0.387)^{\star \star \star}\end{array}$ & $\begin{array}{l}0.832 \\
(0.262)^{\star \star \star}\end{array}$ \\
\hline Dw elling stock $t$ & $\begin{array}{l}-2.875 \\
(0.181)^{\star \star \star}\end{array}$ & $\begin{array}{l}-6.606 \\
(0.331)^{\star \star \star}\end{array}$ & $\begin{array}{l}-15.186 \\
(2.799)^{\star \star \star}\end{array}$ & .. & $\begin{array}{l}-5.955 \\
(2.219)^{\star \star}\end{array}$ & $\begin{array}{l}1.411 \\
(0.649)^{\star \star}\end{array}$ & $\begin{array}{l}-3.007 \\
(0.235)^{\star \star k}\end{array}$ & $\begin{array}{l}-3.381 \\
(0.202)^{\star \star \star}\end{array}$ & $\begin{array}{l}-11.055 \\
(1.129)^{\star \star \star}\end{array}$ & $\begin{array}{l}-0.207 \\
(0.479)\end{array}$ \\
\hline Interest rate $\mathrm{t}$ & $\begin{array}{l}-0.003 \\
(0.003)\end{array}$ & $\begin{array}{l}-0.005 \\
(0.002)^{\star \star}\end{array}$ & $\begin{array}{l}0.002 \\
(0.007)\end{array}$ & $\begin{array}{l}0.004 \\
(0.003)\end{array}$ & $\begin{array}{l}-0.002 \\
(0.004)\end{array}$ & $\begin{array}{l}-0.006 \\
(0.003)^{* *}\end{array}$ & $\begin{array}{l}-0.007 \\
(0.003)^{\star \star \star *}\end{array}$ & $\begin{array}{l}-0.008 \\
(0.004)^{\star}\end{array}$ & $\begin{array}{l}-0.003 \\
(0.004)\end{array}$ & $\begin{array}{l}-0.009 \\
(0.004)^{\star}\end{array}$ \\
\hline Population $\mathrm{t}$ & $\begin{array}{l}0.917 \\
(1.332)\end{array}$ & $\begin{array}{l}14.219 \\
(1.370)^{\star \star \star}\end{array}$ & $\begin{array}{l}24.199 \\
(4.221)^{\star \star \star}\end{array}$ & .. & $\begin{array}{l}-0.176 \\
(39.285)\end{array}$ &.. & $\begin{array}{l}4.326 \\
(2.037)^{\star \star}\end{array}$ & $\begin{array}{l}11.038 \\
(1.260)^{\star \star \star}\end{array}$ & $\begin{array}{l}17.205 \\
(2.265)^{\star \star \star}\end{array}$ & \\
\hline Constant & $\begin{array}{l}-9.606 \\
(12.458)\end{array}$ & $\begin{array}{l}-118.456 \\
(7.330)^{\star \star \star}\end{array}$ & $\begin{array}{l}-108.570 \\
(12.877)^{\star \star \star}\end{array}$ & $\begin{array}{l}-16.317 \\
(1.168)^{\star \star \star}\end{array}$ & $\begin{array}{l}5.609 \\
(441.582)\end{array}$ & $\begin{array}{l}-37.394 \\
(4.658)^{\star \star \star}\end{array}$ & $\begin{array}{l}-49.770 \\
(3.536)^{\star \star \star}\end{array}$ & $\begin{array}{l}-28.162 \\
(3.243)^{\star \star \star}\end{array}$ & $\begin{array}{l}-133.893 \\
(19.964)^{\star \star \star}\end{array}$ & $\begin{array}{l}-7.163 \\
(1.630)^{\star \star \star}\end{array}$ \\
\hline $\begin{array}{l}\text { Number of } \\
\text { observations }\end{array}$ & 97 & 108 & 54 & 122 & 31 & 130 & 133 & 97 & 101 & 113 \\
\hline
\end{tabular}

B. Short run house price relationships by country

\begin{tabular}{|c|c|c|c|c|c|c|c|c|c|c|}
\hline \multicolumn{11}{|c|}{ Dependent variable: 1 st difference log real house prices } \\
\hline & Japan & Netherlands & New Zealand & Norw ay & Poland & Spain & Sw eden & Switzerland & United Kingdom & United States \\
\hline$\Delta$ Income t & $\begin{array}{l}0.105 \\
(0.051)^{\star \star}\end{array}$ & $\begin{array}{l}0.841 \\
(0.236)^{\star \star \star}\end{array}$ & $\begin{array}{l}0.518 \\
(0.205)^{\star \star}\end{array}$ & $\begin{array}{l}0.347 \\
(0.155)^{\star \star}\end{array}$ & $\begin{array}{l}2.241 \\
(2.140)\end{array}$ & $\begin{array}{l}-0.043 \\
(0.228)\end{array}$ & $\begin{array}{l}-0.126 \\
(0.120)\end{array}$ & $\begin{array}{l}0.224 \\
(0.341)\end{array}$ & $\begin{array}{l}1.501 \\
(0.366)^{\star \star \star}\end{array}$ & $\begin{array}{l}0.182 \\
(0.113)\end{array}$ \\
\hline$\Delta$ Dw elling stock $t$ & $\begin{array}{l}0.965 \\
(1.061)\end{array}$ & $\begin{array}{l}-1.871 \\
(0.801)^{\star \star}\end{array}$ & $\begin{array}{l}-0.296 \\
(3.476)\end{array}$ & .. & $\begin{array}{l}2.991 \\
(4.258)\end{array}$ & $\begin{array}{l}. . \\
. .\end{array}$ & $\begin{array}{l}-1.878 \\
(0.803)^{\star \star}\end{array}$ & $\begin{array}{l}-4.262 \\
(3.488)\end{array}$ & $\begin{array}{l}4.466 \\
(5.587)\end{array}$ & $\begin{array}{l}0.715 \\
(0.446)\end{array}$ \\
\hline$\Delta$ Interest rate $\mathrm{t}$ & $\begin{array}{l}0.002 \\
(0.000)^{\star \star \star}\end{array}$ & $\begin{array}{l}-0.001 \\
(0.001)\end{array}$ & $\begin{array}{l}0.001 \\
(0.001)\end{array}$ & $\begin{array}{l}0.000 \\
(0.000)\end{array}$ & $\begin{array}{l}-0.001 \\
(0.002)\end{array}$ & $\begin{array}{l}0.001 \\
(0.000)^{\star *}\end{array}$ & $\begin{array}{l}0.000 \\
(0.000)\end{array}$ & $\begin{array}{l}-0.001 \\
(0.001)\end{array}$ & $\begin{array}{l}0.000 \\
(0.001)\end{array}$ & $\begin{array}{l}0.001 \\
(0.001)^{\star}\end{array}$ \\
\hline$\Delta$ Population $\mathrm{t}$ & $\begin{array}{l}1.357 \\
(1.257)\end{array}$ & $\begin{array}{l}30.625 \\
(8.548)^{\star \star \star}\end{array}$ & $\begin{array}{l}13.924 \\
(3.797)^{\star \star \star}\end{array}$ & & $\begin{array}{l}521.143 \\
(328.478)\end{array}$ & $\begin{array}{l}-0.709 \\
(2.322)\end{array}$ & $\begin{array}{l}4.722 \\
(3.751)\end{array}$ & $\begin{array}{l}8.204 \\
(6.369)\end{array}$ & $\begin{array}{l}25.567 \\
(6.245)^{\star \star \star}\end{array}$ & $\begin{array}{l}. . \\
. .\end{array}$ \\
\hline ECT t-1 & $\begin{array}{l}-0.027 \\
(0.013)^{\star \star}\end{array}$ & $\begin{array}{l}-0.079 \\
(0.035)^{\star \star}\end{array}$ & $\begin{array}{l}-0.085 \\
(0.027)^{\star \star \star}\end{array}$ & $\begin{array}{l}-0.043 \\
(0.014)^{\star \star \star}\end{array}$ & $\begin{array}{l}-0.776 \\
(0.218)^{\star \star \star}\end{array}$ & $\begin{array}{l}-0.032 \\
(0.011)^{\star \star \star}\end{array}$ & $\begin{array}{l}-0.034 \\
(0.014)^{\star \star}\end{array}$ & $\begin{array}{l}-0.048 \\
(0.029)^{*}\end{array}$ & $\begin{array}{l}-0.123 \\
(0.024)^{\star \star \star}\end{array}$ & $\begin{array}{l}-0.040 \\
(0.014)^{\star \star \star}\end{array}$ \\
\hline $\begin{array}{l}\text { Number of } \\
\text { observations } \\
\text { Estimation period }\end{array}$ & 96 & $\begin{array}{c}107 \\
1981 q 1: 2007 q 4\end{array}$ & $\begin{array}{c}53 \\
1994: q 3: 2007: 94\end{array}$ & $\begin{array}{c}121 \\
1979 q 1: 2009: q 2\end{array}$ & $\begin{array}{c}30 \\
1999 \mathrm{q} 2: 2006 \mathrm{q} 4\end{array}$ & $\begin{array}{c}129 \\
1977: 01: 2009: q 2\end{array}$ & $\begin{array}{c}132 \\
1975 q 4: 2008: q 4\end{array}$ & $\begin{array}{c}96 \\
1980 q 4: 2004: q 4\end{array}$ & $\begin{array}{c}100 \\
198094: 200594\end{array}$ & 112 \\
\hline
\end{tabular}

1. Results from the long-run and short-run price relationships, estimated jointly with the investment equations, employing a seemingly unrelated regression (SUR) model. All the specifications include a full set of quarterly dummies. Standard errors are reported in parentheses. ${ }^{* *},{ }^{* *}$, * denote significance at the $1 \%, 5 \%$ and $10 \%$.

Source: OECD estimates. 
Table 2. Supply equations by country: regression results ${ }^{1}$

A. Long run residential investment relationships by country

\begin{tabular}{|c|c|c|c|c|c|c|c|c|c|c|c|}
\hline \multicolumn{12}{|c|}{ Dependent variable: log real residential investment } \\
\hline & Australia & Austria & Belgium & Canada & Denmark & Finland & France & Germany & Ireland & Israel & Italy \\
\hline Real house price $t-1$ & $\begin{array}{c}0.528 \\
(0.054)^{\star \star \star}\end{array}$ & $\begin{array}{c}0.234 \\
(0.057)^{\star \star \star}\end{array}$ & $\begin{array}{c}0.315 \\
(0.028)^{\star * \star}\end{array}$ & $\begin{array}{c}1.187 \\
(0.198)^{\star \star \star \star}\end{array}$ & $\begin{array}{c}1.206 \\
(0.053)^{\star \star \star}\end{array}$ & $\begin{array}{c}0.988 \\
(0.037)^{\star \star \star}\end{array}$ & $\begin{array}{c}0.363 \\
(0.055)^{\star \star \star}\end{array}$ & $\begin{array}{c}0.428 \\
(0.172)^{\star *}\end{array}$ & $\begin{array}{c}0.631 \\
(0.045)^{\star \star \star}\end{array}$ & $\begin{array}{c}0.379 \\
(0.185)^{\star \star}\end{array}$ & $\begin{array}{c}0.258 \\
(0.050)^{\star \star \star}\end{array}$ \\
\hline Real construction cost $\mathrm{t}-1$ & $\begin{array}{l}-0.678 \\
(0.416)\end{array}$ & $\begin{array}{c}-2.600 \\
(0.854)^{\star \star \star *}\end{array}$ & $\begin{array}{c}1.851 \\
(0.274)^{\star \star \star}\end{array}$ & $\begin{array}{l}-0.276 \\
(0.272)\end{array}$ & $\begin{array}{c}-0.410 \\
(0.132)^{\star \star \star}\end{array}$ & $\begin{array}{l}-0.313 \\
(0.273)\end{array}$ & $\begin{array}{c}0.287 \\
(0.218)\end{array}$ & $\begin{array}{c}1.923 \\
(0.255)^{\star \star \star}\end{array}$ & $\begin{array}{l}-0.413 \\
(0.291)\end{array}$ & $\begin{array}{c}0.743 \\
(0.108)^{\star \star \star *}\end{array}$ & $\begin{array}{c}-0.275 \\
(0.118)^{\star \star}\end{array}$ \\
\hline Population t & $\begin{array}{c}1.697 \\
(0.290)^{\star \star \star}\end{array}$ & $\begin{array}{c}6.574 \\
(1.208)^{\star \star \star \star}\end{array}$ & $\begin{array}{c}13.530 \\
(0.747)^{\star \star \star \star}\end{array}$ & $\begin{array}{l}-0.288 \\
(0.319)\end{array}$ & $\begin{array}{c}3.837 \\
(1.583)^{* \star}\end{array}$ & $\begin{array}{l}-0.130 \\
(0.166)\end{array}$ & $\begin{array}{c}1.366 \\
(0.293)^{\star \star \star}\end{array}$ & $\begin{array}{c}5.764 \\
(1.360)^{\star \star \star \star}\end{array}$ & $\begin{array}{c}9.775 \\
(1.819)^{\star \star \star \star}\end{array}$ & $\begin{array}{c}-1.947 \\
(0.121)^{\star \star \star}\end{array}$ & $\begin{array}{c}3.459 \\
(1.161)^{\star \star \star}\end{array}$ \\
\hline Constant & $\begin{array}{c}10.612 \\
(1.223)^{\star \star \star}\end{array}$ & $\begin{array}{c}-25.001 \\
(7.486)^{\star \star \star *}\end{array}$ & $\begin{array}{c}9.719 \\
(1.277)^{\star \star \star}\end{array}$ & $\begin{array}{c}23.126 \\
(3.177)^{\star \star \star}\end{array}$ & $\begin{array}{c}20.019 \\
(0.656)^{\star \star \star}\end{array}$ & $\begin{array}{c}20.452 \\
(0.818)^{\star \star \star}\end{array}$ & $\begin{array}{c}6.912 \\
(3.601)^{\star}\end{array}$ & $\begin{array}{c}-50.541 \\
(15.836)^{\star \star \star}\end{array}$ & $\begin{array}{c}19.512 \\
(1.010)^{\star \star \star}\end{array}$ & $\begin{array}{c}39.432 \\
(1.096)^{\star \star \star}\end{array}$ & $\begin{array}{l}-13.165 \\
(12.943)\end{array}$ \\
\hline Number of observations & 109 & 69 & 93 & 101 & 109 & 69 & 89 & 151 & 109 & 48 & 53 \\
\hline \multicolumn{12}{|c|}{ Panel B: Short run residential investment relationships by country } \\
\hline \multicolumn{12}{|c|}{ Dependent variable: 1st difference log real residential investment } \\
\hline & Australia & Austria & Belgium & Canada & Denmark & Finland & France & Germany & Ireland & Israel & Italy \\
\hline$\Delta$ Real house price $\mathrm{t}-1$ & $\begin{array}{c}1.205 \\
(0.208)^{\star \star \star *}\end{array}$ & $\begin{array}{c}0.04 \\
-0.035\end{array}$ & $\begin{array}{c}0.244 \\
(0.163)\end{array}$ & $\begin{array}{c}0.392 \\
(0.152)^{\star \star \star *}\end{array}$ & $\begin{array}{c}0.749 \\
(0.174)^{\star \star \star}\end{array}$ & $\begin{array}{c}0.803 \\
(0.132)^{\star k \star}\end{array}$ & $\begin{array}{c}0.441 \\
(0.092)^{\star \star \star}\end{array}$ & $\begin{array}{c}0.466 \\
(0.758)\end{array}$ & $\begin{array}{c}0.238 \\
(0.118)^{\star *}\end{array}$ & $\begin{array}{c}0.061 \\
(0.159)\end{array}$ & $\begin{array}{c}0.102 \\
(0.234)\end{array}$ \\
\hline$\Delta$ Real construction cost $\mathrm{t}-1$ & $\begin{array}{l}-0.628 \\
(0.537)\end{array}$ & $\begin{array}{c}0.723 \\
(0.356)^{* \star}\end{array}$ & $\begin{array}{c}0.690 \\
(0.315)^{\star \star}\end{array}$ & $\begin{array}{l}-0.083 \\
(0.258)\end{array}$ & $\begin{array}{l}-0.725 \\
(0.456)\end{array}$ & $\begin{array}{c}0.457 \\
(0.469)\end{array}$ & $\begin{array}{c}0.023 \\
(0.120)\end{array}$ & $\begin{array}{c}1.246 \\
(0.648)^{\star}\end{array}$ & $\begin{array}{l}-0.028 \\
(0.192)\end{array}$ & $\begin{array}{c}-0.935 \\
(6.014)^{\star}\end{array}$ & $\begin{array}{l}-0.282 \\
(0.260)\end{array}$ \\
\hline$\Delta$ Population $\mathrm{t}$ & $\begin{array}{c}0.291 \\
(1.765)\end{array}$ & $\begin{array}{c}18.743 \\
(3.815)^{\star \star \star \star ~}\end{array}$ & 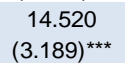 & $\begin{array}{c}1.130 \\
(3.229)\end{array}$ & $\begin{array}{l}-4.944 \\
(9.202)\end{array}$ & $\begin{array}{l}-3.736 \\
(2.909)\end{array}$ & $\begin{array}{l}-8.280 \\
(5.093)\end{array}$ & $\begin{array}{c}13.697 \\
(10.394)\end{array}$ & $\begin{array}{c}16.366 \\
(12.617)\end{array}$ & $\begin{array}{l}-10.961 \\
(0.159)\end{array}$ & $\begin{array}{l}10.389 \\
(6.609)\end{array}$ \\
\hline ECT t-1 & $\begin{array}{c}-0.166 \\
(0.048)^{\star \star \star}\end{array}$ & $\begin{array}{c}0.068 \\
(0.027)^{\star *}\end{array}$ & $\begin{array}{l}-0.105 \\
(0.047)^{\star \star}\end{array}$ & $\begin{array}{c}-0.058 \\
(0.034)^{\star}\end{array}$ & $\begin{array}{c}-0.216 \\
(0.068)^{\star \star \star}\end{array}$ & $\begin{array}{c}-0.310 \\
(0.094)^{\star \star \star}\end{array}$ & $\begin{array}{c}-0.052 \\
(0.024)^{\star \star}\end{array}$ & $\begin{array}{l}-0.200 \\
(0.052)^{\star \star \star}\end{array}$ & $\begin{array}{c}-0.113 \\
(0.047)^{* *}\end{array}$ & $\begin{array}{c}-0.323 \\
(0.097)^{\star \star \star}\end{array}$ & $\begin{array}{c}-0.622 \\
(0.127)^{\text {*k* }}\end{array}$ \\
\hline Number of observations & 108 & 68 & 93 & 100 & 108 & 68 & 88 & 150 & 108 & 42 & 52 \\
\hline
\end{tabular}

$\begin{array}{lllllllllllllllll}\text { Estimation period } & 1982 q 2: 2009 q 2 & 1986 q 4: 2003 q 4 & 1984 q 4: 2007 q 4 & 1980 q 4: 2005 q 4 & 1980 q 4: 2007 q 4 & 1988 q 4-2005 q 4 & 1983 q 4: 2005 q 4 & 1970 q 2: 2007 q 4 & 1980 q 4-2007 q 4 & 1995 q 2: 2009 q 1 & 1990 q 4: 2003 q 4\end{array}$

1. Results from the long-run and short-run investment relationships, which are estimated jointly with the price equations, employing a seemingly unrelated regression (SUR) model. All the specifications include a full set of quarterly dummies. Standard errors are reported in parentheses. ***, **, * denote significance at the $1 \%, 5 \%$ and $10 \%$.

Source: OECD estimates. 
Table 2. Supply equations by country: regression results ${ }^{1}$ (cont'd)

A. Long run residential investment relationships by country

\begin{tabular}{|c|c|c|c|c|c|c|c|c|c|c|}
\hline & Japan & Netherlands & New Zealand & Norway & Poland & Spain & Sw eden & Switzerland & United Kingdom & United States \\
\hline Real house price $t-1$ & 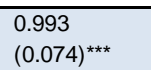 & $\begin{array}{l}0.186 \\
(0.061)^{\star \star \star}\end{array}$ & $\begin{array}{l}0.705 \\
(0.145)^{\star \star \star}\end{array}$ & $\begin{array}{l}0.486 \\
(0.024)^{\star \star \star \star ~}\end{array}$ & $\begin{array}{l}0.442 \\
(0.122)^{\star \star \hbar k}\end{array}$ & $\begin{array}{l}0.452 \\
(0.051)^{\star \star \star \star ~}\end{array}$ & $\begin{array}{l}1.381 \\
(0.193)^{\star \star \star}\end{array}$ & $\begin{array}{l}0.146 \\
(0.055)^{\star k \text { k* }}\end{array}$ & $\begin{array}{l}0.395 \\
(0.029)^{\star \star \star \star ~}\end{array}$ & $\begin{array}{l}2.014 \\
(0.376)^{\star \star \star \star}\end{array}$ \\
\hline Real construction cost $t-1$ & $\begin{array}{l}0.059 \\
(0.230)\end{array}$ & $\begin{array}{l}-0.542 \\
(0.208)^{* k}\end{array}$ & $\begin{array}{l}-1.040 \\
(0.381)^{\star \star \star}\end{array}$ & $\begin{array}{l}-1.039 \\
(0.116)^{\star k \star}\end{array}$ & $\begin{array}{l}-1.275 \\
(0.782)\end{array}$ & $\begin{array}{l}0.126 \\
(0.192)\end{array}$ & $\begin{array}{l}-0.275 \\
(0.497)\end{array}$ & $\begin{array}{l}-0.066 \\
(0.020)^{\star \star \star}\end{array}$ & $\begin{array}{l}0.374 \\
(0.078)^{\star \star \star}\end{array}$ & $\begin{array}{l}-3.459 \\
(0.600)^{\star \star \star}\end{array}$ \\
\hline Population $\mathrm{t}$ & $\begin{array}{l}1.425 \\
(0.391)^{\star \star \star}\end{array}$ & $\begin{array}{l}3.016 \\
(0.384)^{\star \star \star *}\end{array}$ & $\begin{array}{l}0.537 \\
(0.691)\end{array}$ & $\begin{array}{l}. . \\
. .\end{array}$ & $\begin{array}{l}-6.566 \\
(6.800)\end{array}$ & $\begin{array}{l}0.024 \\
(0.371)\end{array}$ & $\begin{array}{l}36.232 \\
(5.713)^{\star \star \star \star}\end{array}$ & $\begin{array}{l}7.485 \\
(1.356)^{\star \star \star \star *}\end{array}$ & $\begin{array}{l}3.935 \\
(0.916)^{\star \star k \star}\end{array}$ & $\begin{array}{l}6.909 \\
(0.795)^{\star \star \star}\end{array}$ \\
\hline Constant & $\begin{array}{l}9.068 \\
(4.258)^{\star \star}\end{array}$ & $\begin{array}{l}-3.647 \\
(3.572)\end{array}$ & $\begin{array}{l}19.527 \\
(5.120)^{\star \star \star}\end{array}$ & $\begin{array}{l}27.534 \\
(0.575)^{\star \star \star k}\end{array}$ & $\begin{array}{l}29.500 \\
(2.701)^{\star \star \star \star}\end{array}$ & $\begin{array}{l}21.103 \\
(3.860)^{\star \star \star x *}\end{array}$ & $\begin{array}{l}10.108 \\
(1.631)^{\star \star \star \star}\end{array}$ & $\begin{array}{l}20.740 \\
(0.380)^{\star \star \star \star}\end{array}$ & $\begin{array}{l}20.029 \\
(0.443)^{\star \star \star \star *}\end{array}$ & $\begin{array}{l}-66.341 \\
(10.903)^{\star \star \star}\end{array}$ \\
\hline Number of observations & 97 & 108 & 54 & 122 & 31 & 130 & 133 & 97 & 101 & 113 \\
\hline
\end{tabular}

B. Short run residential investment relationships by country

Dependent variable: 1 st difference log real residential investment

\begin{tabular}{|c|c|c|c|c|c|c|c|c|c|c|}
\hline & Japan & Netherlands & New Zealand & Norway & Poland & Spain & Sw eden & Switzerland & United Kingdom & United States \\
\hline$\Delta$ Real house price $t-1$ & $\begin{array}{l}0.668 \\
(0.342)^{*}\end{array}$ & $\begin{array}{l}0.470 \\
(0.284)\end{array}$ & $\begin{array}{l}1.411 \\
(0.530)^{\star \star \star}\end{array}$ & $\begin{array}{l}0.399 \\
(0.119)^{\star \star \star}\end{array}$ & $\begin{array}{l}0.079 \\
(0.093)\end{array}$ & $\begin{array}{l}0.236 \\
(0.080)^{\star k \star}\end{array}$ & $\begin{array}{l}0.479 \\
(0.158)^{\star \star \star k}\end{array}$ & $\begin{array}{l}0.040 \\
(0.041)\end{array}$ & $\begin{array}{l}0.810 \\
(0.237)^{\star \star \star}\end{array}$ & $\begin{array}{l}2.497 \\
(0.396)^{\star \star \star}\end{array}$ \\
\hline$\Delta$ Real construction cost $\mathrm{t}-1$ & $\begin{array}{l}-0.204 \\
(0.519)\end{array}$ & $\begin{array}{l}0.482 \\
(0.335)\end{array}$ & $\begin{array}{l}0.241 \\
(0.721)\end{array}$ & $\begin{array}{l}-0.162 \\
(0.156)\end{array}$ & $\begin{array}{l}0.593 \\
(0.546)\end{array}$ & $\begin{array}{l}-0.053 \\
(0.228)\end{array}$ & $\begin{array}{l}-0.185 \\
(0.277)\end{array}$ & $\begin{array}{l}0.003 \\
(0.012)\end{array}$ & $\begin{array}{l}0.137 \\
(0.098)\end{array}$ & $\begin{array}{l}-1.625 \\
(0.713)^{\star \star}\end{array}$ \\
\hline$\Delta$ Population $\mathrm{t}$ & $\begin{array}{l}-7.258 \\
(7.946)\end{array}$ & $\begin{array}{l}26.029 \\
(28.812)\end{array}$ & $\begin{array}{l}24.244 \\
(17.089)\end{array}$ & $\begin{array}{l}. . \\
. .\end{array}$ & $\begin{array}{l}10.251 \\
(14.382)\end{array}$ & $\begin{array}{l}3.169 \\
(3.387)\end{array}$ & $\begin{array}{l}5.001 \\
(8.285)\end{array}$ & $\begin{array}{l}-0.465 \\
(1.624)\end{array}$ & $\begin{array}{l}6.201 \\
(9.610)\end{array}$ & $\begin{array}{l}5.038 \\
(11.250)\end{array}$ \\
\hline ECT $t-1$ & $\begin{array}{l}-0.136 \\
(0.041)^{* \star *}\end{array}$ & $\begin{array}{l}-0.775 \\
(0.094)^{\text {*k* }}\end{array}$ & $\begin{array}{l}-0.429 \\
(0.113)^{\star \star \star *}\end{array}$ & $\begin{array}{l}-0.162 \\
(0.039)^{\star \star \star \star}\end{array}$ & $\begin{array}{l}-0.300 \\
(0.126)^{\star *}\end{array}$ & $\begin{array}{l}-0.076 \\
(0.030)^{\star *}\end{array}$ & $\begin{array}{l}-0.126 \\
(0.018)^{\star \star \star k}\end{array}$ & $\begin{array}{l}-0.087 \\
(0.014)^{* k \star}\end{array}$ & $\begin{array}{l}-0.277 \\
(0.078)^{\star * \star *}\end{array}$ & $\begin{array}{l}-0.072 \\
(0.031)^{* *}\end{array}$ \\
\hline Number of observations & 96 & 107 & 53 & 121 & 30 & 129 & 132 & 96 & 100 & 112 \\
\hline
\end{tabular}

Estimation period

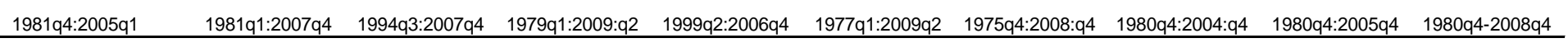

1. Results from the long-run and short-run investment relationships, which are estimated jointly with the price equations, employing a seemingly unrelated regression (SUR) model. All the specifications include a full set of quarterly dummies. Standard errors are reported in parentheses. ${ }^{* *},{ }^{* *},{ }^{*}$ denote significance at the $1 \%, 5 \%$ and $10 \%$.

Source: OECD estimates. 


\subsection{Short-run estimates}

27. Turning to the short-run adjustment equations, in the price equation the growth rates of income and population have a positive effect on price inflation, while increases in the housing stock lead to house price deflation. The effect of interest rates changes on price changes is typically non significant and when significant yields a counterintuitive positive effect on price growth for some countries (5 of them), which may indicate that the estimation framework is unable to control for the potential simultaneity bias between interest rates and house prices. The coefficients on the error correction term in the price equation are significant and range between -0.027 and -0.776 , suggesting that there are wide differences across countries in the implied speed of price adjustment. ${ }^{9}$ Prices adjust fast to shocks in countries like Poland and Austria, where about $100 \%$ of the gap between actual and equilibrium price is closed within a year, whereas the reaction of prices is slower in, for instance, Japan and Denmark where only about $10 \%$ of the gap is closed within a year.

28. On the supply side, estimates of the short-run investment equation for the different countries indicate that the growth in lagged prices has a significant positive effect on the growth of investment. However, the other explanatory variables are only significant for few countries. Changes in construction costs and population do not typically influence changes in investment, which may be explained by the fact that typically in the short-run changes in construction costs and population are not large. The coefficients on the error-correction term have the expected negative sign and are significant ranging from -0.052 (France) to -0.775 (the Netherlands). These estimates imply that between $20 \%$ and over $100 \%$ of the differences between actual and equilibrium investment are closed within a year depending on the country. There appears to be a positive relationship between the price-responsiveness of housing supply and the speed of adjustment of investment for countries with a very responsive housing supply (e.g. the United States and Sweden) and for countries with a low responsiveness of housing supply (e.g. Switzerland and Belgium). The relationship between the long-term responsiveness of housing supply and the speed of adjustment is more tenuous for the rest of countries. On average investment and prices appear to adjust in similar fashion to shocks.

\subsection{Comparison of the findings relative to other studies}

29. Various studies have estimated the price elasticity of housing supply for a reduced number of countries (See e.g. Vermeulen and Rouwendal, 2007 for a review), mostly focusing on the United States and the United Kingdom. Even though, as discussed above, the stock-flow model is the theoretical framework typically used to analyse the housing sector, its empirical implementation widely differs across studies and comparisons of estimates across studies is problematic due to differences in analytical frameworks, specification of the supply function (stock, new dwellings or construction permits etc.) and period coverage. Even so, evidence from other studies can serve as a rough benchmark for the estimates of the long-term elasticity of supply reported here. Table 3 summarises these elasticity estimates, together with the speed of adjustment of investment estimates..

$9 \quad$ The size of the error correction term in the price equation for Poland seems implausibly large $(-0.776)$ implying that $300 \%$ of the difference between the actual and the equilibrium price is closed within a year. The error-correction term in the price equation for Israel is not significant, which could be due to the short time series data available. 
Table 3. Price responsiveness of housing supply and speed of supply response

\begin{tabular}{|c|c|c|}
\hline & $\begin{array}{c}\text { Price responsiveness of } \\
\text { housing supply }{ }^{1}\end{array}$ & $\begin{array}{c}\text { Speed of } \\
\text { supply response }\end{array}$ \\
\hline Australia & $0.528(0.054)^{\star \star \star}$ & $-0.166(0.048)^{\star \star \star}$ \\
\hline Austria & $0.234(0.057)^{\star \star \star}$ & $0.068(0.027)^{\star \star}$ \\
\hline Belgium & $0.315(0.028)^{\star \star \star}$ & $-0.105(0.047)^{\star \star}$ \\
\hline Canada & $1.187(0.198)^{\star \star \star}$ & $-0.058(0.034)^{*}$ \\
\hline Denmark & $1.206(0.053)^{\star \star \star}$ & $-0.216(0.068)^{\star \star \star}$ \\
\hline Finland & $0.988(0.037)^{\star \star \star}$ & $-0.310(0.094)^{\star \star \star *}$ \\
\hline France & $0.363(0.055)^{\star \star \star}$ & $-0.052(0.024)^{\star \star}$ \\
\hline Germany & $0.428(0.172)^{\star \star}$ & $-0.200(0.052)^{\star \star \star}$ \\
\hline Ireland & $0.631(0.045)^{\star \star \star}$ & $-0.113(0.047)^{\star \star}$ \\
\hline Israel & $0.379(0.185)^{\star \star}$ & $-0.323(0.097)^{\star \star \star}$ \\
\hline Italy & $0.258(0.050)^{\star \star \star}$ & $-0.622(0.127)^{\star \star \star}$ \\
\hline Japan & $0.993(0.074)^{\star \star \star}$ & $-0.136(0.041)^{\star \star \star}$ \\
\hline Netherlands & $0.186(0.061)^{\star \star \star}$ & $-0.775(0.094)^{\star \star \star}$ \\
\hline New Zealand & $0.705(0.145)^{\star \star \star}$ & $-0.429(0.113)^{\star \star \star}$ \\
\hline Norw ay & $0.486(0.024)^{\star \star \star}$ & $-0.162(0.039)^{\star \star \star *}$ \\
\hline Poland & $0.442(0.122)^{\star \star \star}$ & $-0.300(0.126)^{\star \star}$ \\
\hline Spain & $0.452(0.051)^{\star \star \star}$ & $-0.076(0.030)^{\star \star}$ \\
\hline Sw eden & $1.381(0.193)^{\star \star \star}$ & $-0.126(0.018)^{\star \star \star}$ \\
\hline Sw itzerland & $0.146(0.055)^{\star \star \star}$ & $-0.087(0.014)^{\star \star \star}$ \\
\hline United Kingdom & $0.395(0.029)^{\star \star \star}$ & $-0.277(0.078)^{\star \star \star}$ \\
\hline United States & $2.014(0.376)^{\star \star \star}$ & $-0.072(0.031)^{\star \star}$ \\
\hline
\end{tabular}

1. Coefficient on lagged prices in the long-run investment equation.

2. Coefficient on the error correction term in the short-run investment equation.

Sources: OECD estimates.

30. In order to draw comparisons between the estimates reported in Table 3 and other studies, countries can be grouped into three categories depending on how price-responsive supply is:

- First, new housing supply appears to be quite responsive to prices in North America (the United States and Canada) and in some Nordic countries (Sweden and Denmark). With the abovementioned caveats in mind, the available evidence, broadly, confirms these findings. Most studies for the United States suggest a high degree of responsiveness of housing supply to price changes, with estimates ranging from 0.5 to 3 depending on the estimation period and analytical framework (e.g. Poterba, 1984; Mayo and Shepard, 1991; Harter and Dreiman, 2004). Previous evidence provided by the OECD (Hüfner and Lundsgard, 2007) also found a high responsiveness of new housing supply in Sweden (1.4 compared to 1.38 found in this study). By contrast, evidence reported in Swank et al. (2002) points to a elasticity of supply of 0.66 for Denmark much lower than the one found in this study. The difference in the estimates may stem not only from the different estimation frameworks but also from the much longer period covered by the present study.

- Second, housing supply appears to be quite unresponsive to prices in Switzerland and the Netherlands and fairly rigid in Austria, Italy, Belgium, France and the United Kingdom. Available evidence for this group of countries focuses on the United Kingdom and the Netherlands. It suggests that housing supply is particularly inelastic in these countries, translating into poor supply responses to demand shocks and strong rises in house prices (e.g. André, 2010; Barker, 2004; Vermeulen and Rouwendal, 2008). Vermeulen and Rouwendal (2008) also find that housing supply in the Netherlands hardly responds to prices in the long-run. For the United Kingdom, Swank et al. (2002) report a low elasticity of supply of 0.45 over 1976 to 1999 using the number of permits as a measurement of new housing supply. Econometric evidence on the price responsiveness of housing supply for Austria, Italy, Belgium and France is lacking. Figures 1 and 2 show that prices have risen more than investment over the recent past in these countries, suggesting relatively low housing supply responsiveness. 
- $\quad$ Third, a last group of countries display intermediate housing supply responsiveness, including New Zealand, Ireland, Australia, Norway and Spain. Evidence for this group of countries is only available for New Zealand and Spain. For New Zealand, Grimes (2007) finds a elasticity of housing supply between 0.5 and 1.1, in line with the evidence reported here (0.71). For Spain, Taltavull (2008) finds that, despite the great amount of residential construction carried on since the mid-1990s, the long-run elasticity of housing supply over a longer time period (from 1987 to 2004) is not as high as expected; around 0.47, thus slightly lower than the one found here of 0.57 over 1977 to 2009.

\section{Factors influencing the responsiveness of housing supply to prices}

31. Cross-country differences in the long-run price responsiveness of housing supply can be related to both policy and non-policy factors. First, geographical and demographic conditions, such as physical limitations on land for development, can restrict the supply of land in certain areas and have a negative impact on the supply of housing in the long run. Indeed, a simple cross-country correlation shows that the estimated housing supply elasticity is lower in more densely populated countries (Figure 4, Panel A). The same appears to be true within countries. For instance, based on existing estimates by Green et al. (2005) on the responsiveness of housing supply for US cities, Panel B in the same figure suggests that supply is more rigid in cities with a greater population density.

32. But, government policies can also have a bearing for housing supply. For instance, land-use and planning policies are intended to reduce negative externalities that can be associated with new housing construction, but if they are poorly designed they may also restrict supply responsiveness. For instance, Figure 5 shows that housing supply responsiveness tends to be lower in countries where it takes longer to acquire a building permit. ${ }^{10}$ Interpreting this correlation causally, an efficient design and enforcement of land-use regulation would have the potential for making housing supply more responsive to prices. This illustrative finding is also evident across cities in the United States, providing further support for the notion that housing supply responsiveness is related to regulations on land-use and planning.

10 This correlation is robust to controlling for scarcity of land in a simple regression explaining the elasticity of supply with land-use regulation and scarcity of land. In addition, the correlation is also evident if the lifespan of building permits are used as a regulatory measure instead of the waiting time for obtaining a building permit. 
Figure 4. Price responsiveness of supply and scarcity of land

A. Cross-country correlation

Supply responsiveness ${ }^{1}$

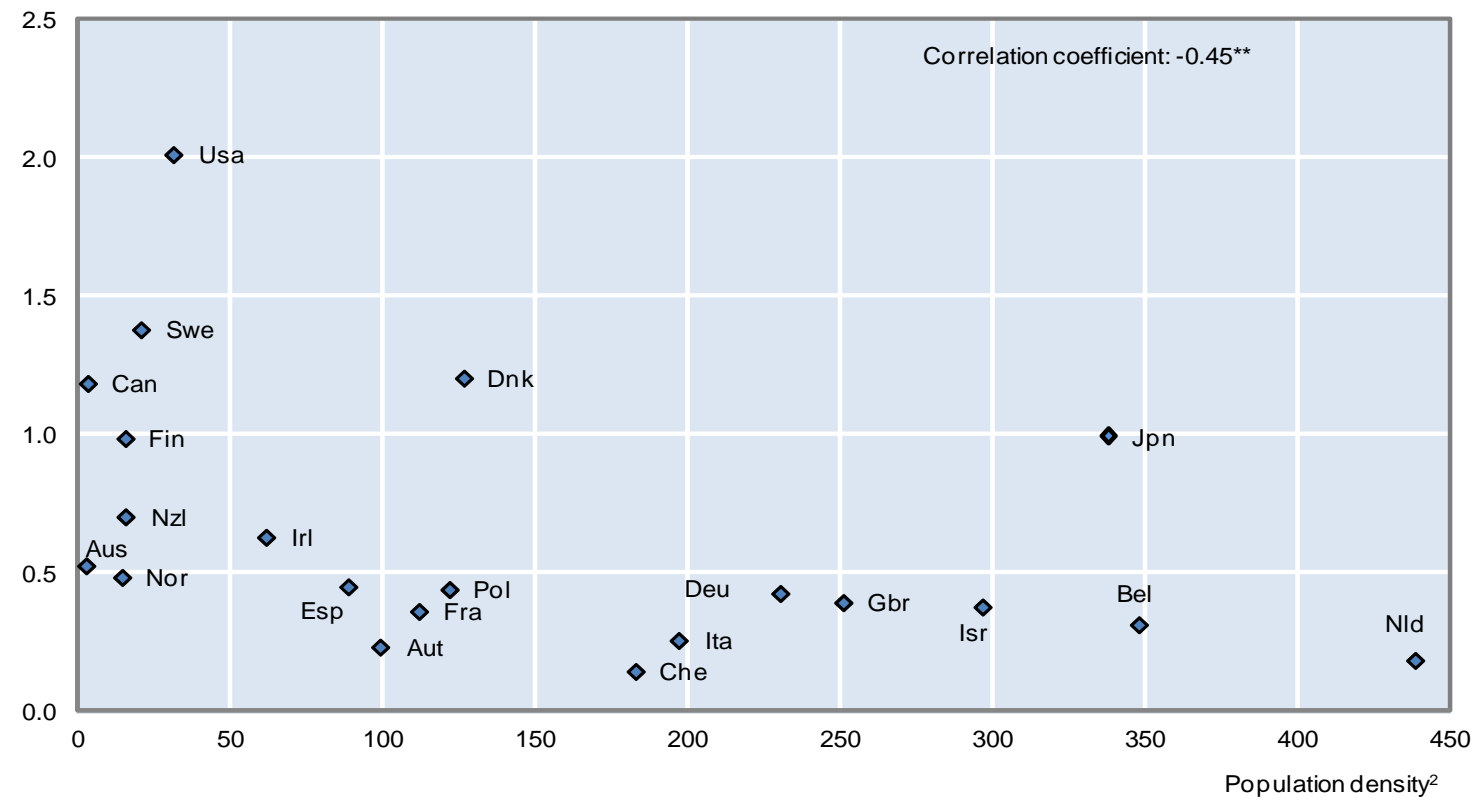

B. Correlation across United States cities

Supply responsiveness ${ }^{1}$

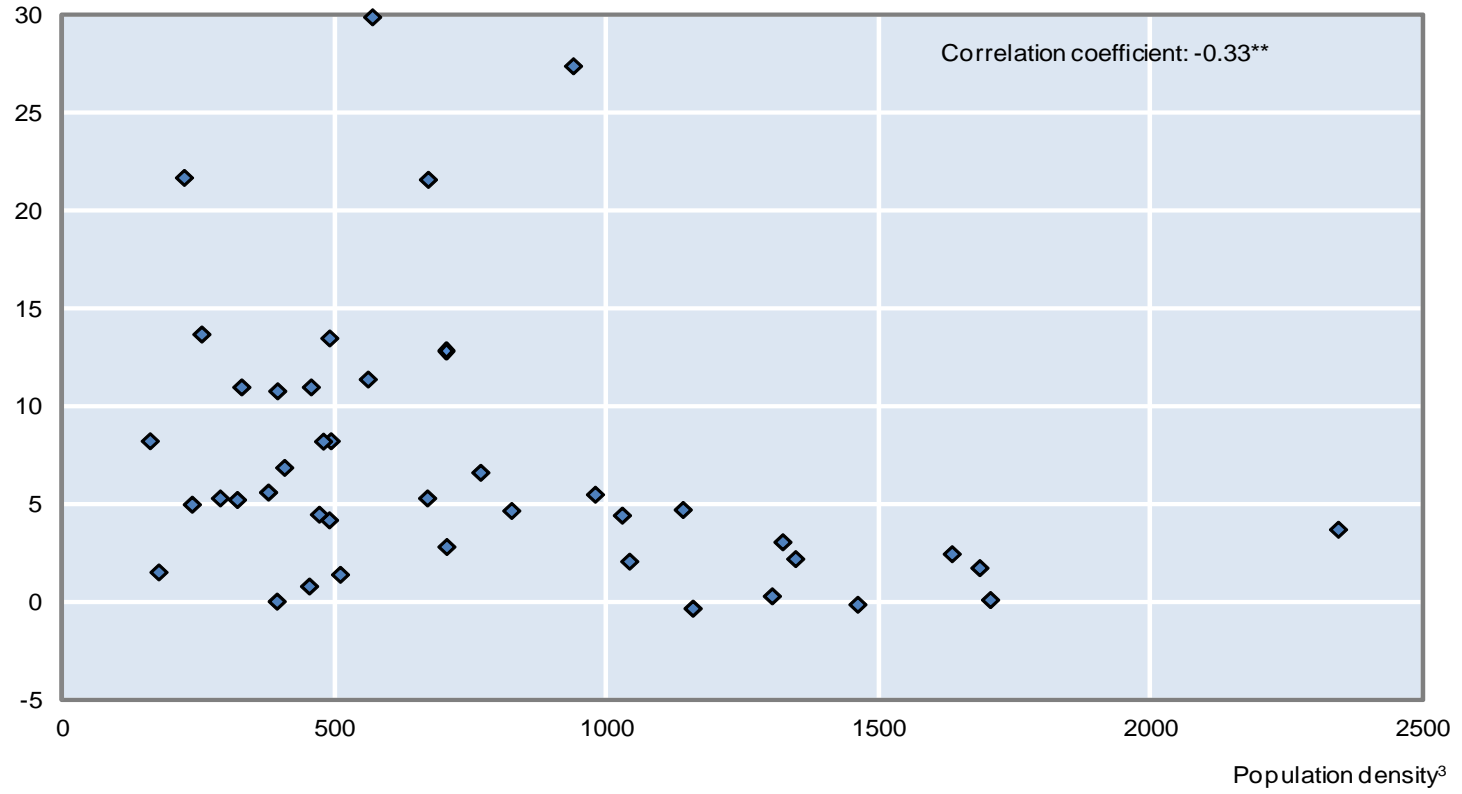

1. OECD estimates of country-specific supply responsiveness and estimates of supply responsiveness for United States cities taken from Green et al. (2005). ** Denotes significance at the 5\% level.

2. Population density measured as population per $\mathrm{km}^{2}$.

3. Population density measured as population per square mile.

Sources: OECD estimations, United Nations (2007) and Green et al. (2005). 
Figure 5. Price responsiveness of supply and land-use regulations

A. Cross-country correlation

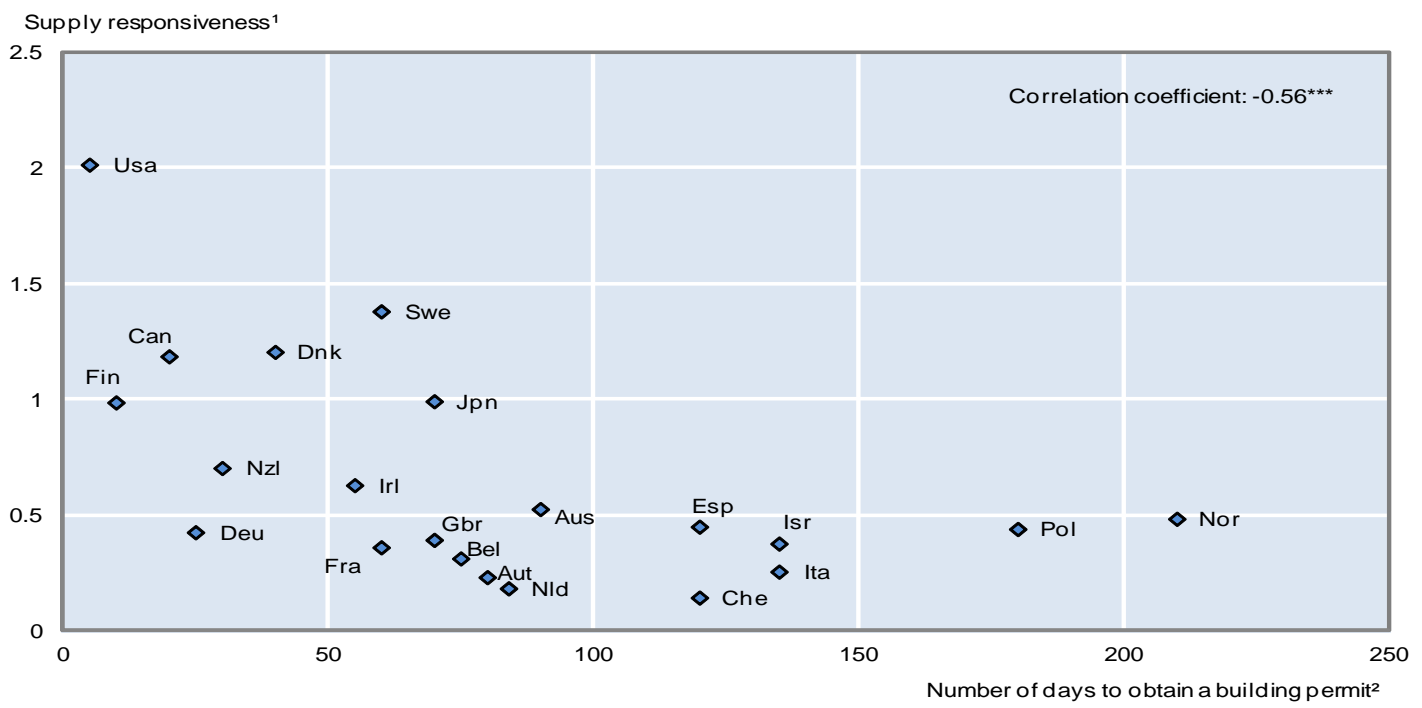

B. Correlation across United States cities

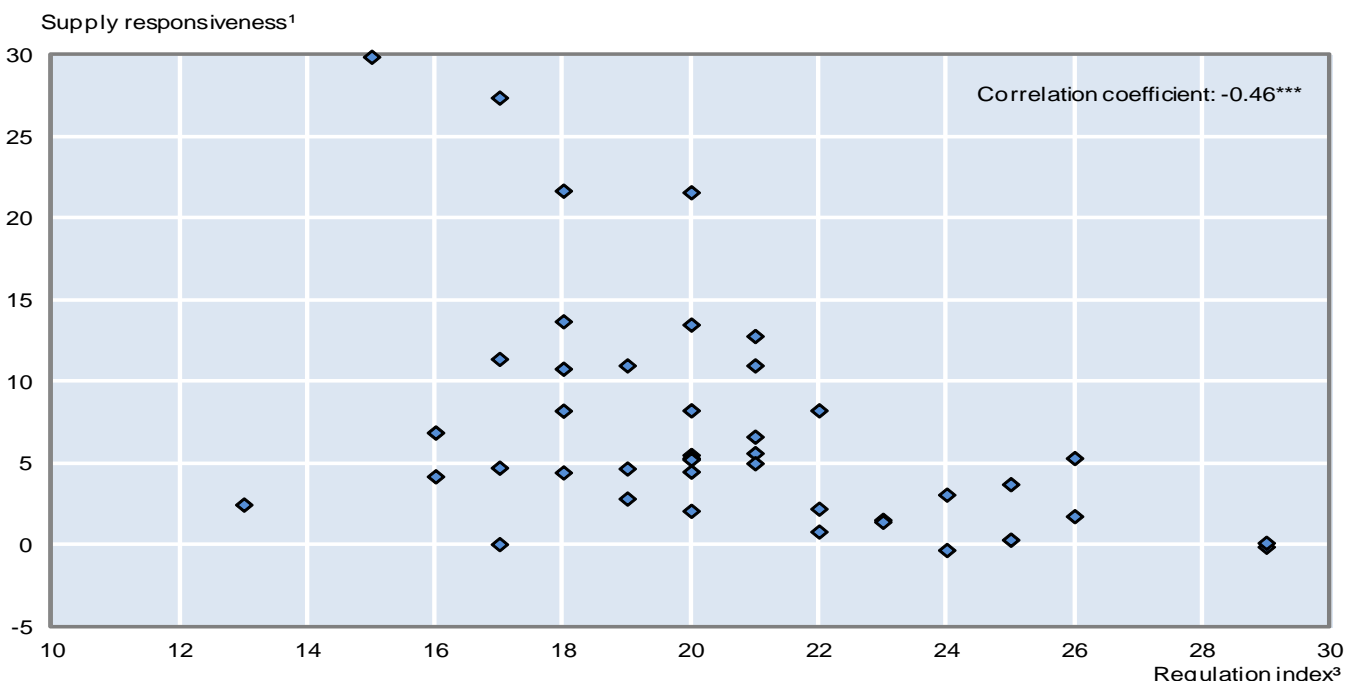

1. OECD estimates of country-specific supply responsiveness and estimates of supply responsiveness for United States cities taken from Green et al. (2005). *** Denotes significance at the 1\% level.

2. The number of days to obtain a building permit is obtained from the World Bank Doing Business (2009) indicators.

3. The land-use regulation index captures approval time of building permits, available land for residential housing and access to adequate infrastructure and ranges between 7-35 (increasing in regulation) (see Malpezzi, 1996).

Sources: OECD estimations, World Bank Doing Business (2009), Malpezzi (1996) and Green et al. (2005).

33. However, while there is an emerging consensus that local land-use regulations have become a binding constraint on the supply of new housing units in some countries, there is much less of a consensus on the magnitude of the impact (e.g. Gyourko, 2009 for an overview). Apart from regulations on land-use, the provision of infrastructure and other public services complementary to housing, such as road junctions 
or water drainage, is also likely to influence supply, though hard evidence of this link is not available (e.g. Barker, 2008, for a discussion).

34. Housing supply responsiveness is also potentially affected by the degree of competition in the residential construction industry (Barker, 2004). Usually, available studies find that average mark-ups in the construction industry are typically low relative to other non-manufacturing industries (Molnar and Bottini, 2010; Bouis and Klein, 2009), although the extent of competition varies across countries (See Andrews et al., 2011). ${ }^{11}$ Taken as a whole, the construction industry is typically characterised by a large number of relatively small firms. However, thinking of construction as an atomistic industry may be misleading as only a limited number of contractors are capable of managing large projects. In general, competition is low among large contractors, while it usually tends to be high among smaller subcontractors (OECD, 2008). In the light of this, implementing an effective competition policy which, among other things, enforces anti-trust regulation and hinders collusive behaviour in the construction sector would seem to be important for improving supply responsiveness.

35. Finally, a number of studies illustrate the adverse effects of poorly designed rent regulations on housing supply (e.g. Arnott, 1995; Ellingsen and Englund, 2003). Stringent rent regulations potentially discourage new construction and maintenance by capping the price of rentals, thus lowering the net return on residential investments for rental purposes and constraining housing supply (Sims, 2007; Arnott, 2003). In line with this, illustrative correlation analysis (Andrews et al., 2011) shows that across countries, stricter rent control tends to be associated with lower quantity and quality of rental housing, as measured by the share of tenants lacking space and those reporting sub-standard housing in terms of a leaking roof.

\section{Economic and policy implications of the price responsiveness of housing supply}

36. The responsiveness of housing supply could affect housing market developments and impact the wider economy through its effects on house prices in various ways. In the face of demand shocks, an unresponsive housing supply can lead to higher prices compared to a more responsive housing supply environment, constraining households' private consumption and portfolio decisions in the short to medium term. In addition, constraints in the supply of housing may alter local employment and wage dynamics across residential areas with repercussions for labour mobility. However, the flip side is that in flexiblesupply countries, housing investment adjusts more rapidly to large changes in demand and contributes to more cyclical swings in economic growth, as witnessed by recent developments in OECD housing markets. Despite this trade-off, in the longer term a more flexible supply of housing is generally desirable as it allows a better match of housing construction to changes in housing demand patterns across the territory and facilitates the reallocation of workers across regions. The last part of this section outlines some policy options to increase the responsiveness of housing supply.

\subsection{Housing price developments}

37. Evidence suggests that regions with high supply responsiveness have relatively small price rises following demand shocks (e.g. Grimes and Aitken, 2006). Recent cross-country estimates (Andrews et al., 2011, Box 4) indeed suggest that positive housing demand shocks caused by either financial, labour market or demographic shocks translate into larger increases in real house prices in countries with more rigid housing supply. The magnitude of these effects is reasonably large. For instance, if the supply elasticity is

However, there is no apparent cross-country correlation between available measures of mark-ups in the construction industry and the estimated supply responsiveness. This may possibly reflect that average estimates of mark-ups are hard to interpret as they disguise large variations between different segments of the market, and in similar vein average elasticities hide differences in supply responsiveness across regions. 
half a standard deviation below the median (among the countries included in the analysis) the increase in house prices associated with an increase in demand caused by financial deregulation is roughly $50 \%$ larger than if the supply elasticity was at the median. This finding is consistent with recent empirical evidence for the United States, which shows that the relaxation of interstate banking regulations resulted in larger increases in house prices in counties with less elastic housing supply (Favara and Imbs, 2009).

38. Other recent cross-country estimates also point to a negative association between housing supply responsiveness and real house price variability (Andrews 2010). They suggest that the variability of house prices is likely to be higher in countries where the supply of housing is price-inelastic, controlling for the size of shocks to housing demand. This finding is in line with evidence by Glaeser et al. (2008) which suggests that housing prices increase more during "bubbles" and housing price "bubbles" are more common and last longer in areas where supply is inelastic.

39. These effects of supply restrictions on house price volatility may have implications for aggregate demand and economic activity because such volatility may affect private demand and residential investment. For instance, there is evidence that price volatility affects the incentives to construct new housing and the level of activity in the construction sector (Topel and Rosen, 1988).

\subsection{Labour market}

40. Housing supply responsiveness to prices may also influence the functioning of labour markets and how they adjust to changing economic conditions. Constraints on the supply of housing can alter local employment and wage dynamics in those areas in which restrictions are more severe (Saks, 2008). For instance, in the face of a positive demand shock, an increase in labour demand may translate into less employment growth and higher wages in areas where it is relatively more difficult to build new housing in order to accommodate an inflow of workers. Constraints on housing supply will mean that prices, rather than quantity will rise, leading to higher housing costs and, thus, putting pressure on nominal wages. For instance, Saks (2008) finds that the long-run response of employment to an increase in labour demand is about $20 \%$ lower in metropolitan areas with restrictive housing supply regulations.

41. Housing supply conditions can also influence the reallocation of workers over the national territory as relative house prices influence migration decisions across labour market areas. Large price differentials between areas caused, for instance, by region-specific shocks in combination with rigid housing supply, can lead to lower geographical mobility since households in lower-priced areas have a larger credit hurdle to clear if they wish to move to the higher priced region (Saks, 2008; Barker, 2004; Cameron and Muellbauer, 1998). Housing price differentials may also curb mobility, if homeowners in high inflation areas are unwilling to give up their expected capital gains and move to low house price inflation areas. Recent cross-country household-level empirical evidence by Caldera Sánchez and Andrews (2011) shows that in countries and cities with more responsive housing supply residential mobility tends to be much higher than in countries and cities with less responsive housing supply. Thus, by preventing people from moving across locations, policies that constrain the supply of housing have an impact on the efficient allocation of labour and economic activity across regions.

\subsection{Policy reforms to enhance supply responsiveness}

42. A number of structural policy reforms, notably in the areas of housing regulations and taxation, offer potential means to increase the responsiveness of housing supply and to avoid excessive increases in house prices and negative impacts on the economy (for a detailed discussion see Andrews et al., 2011). Land-use policies and regulations could ensure a more efficient use of land in countries where scarcity of land restricts supply and pushes up price. In addition, in some countries there is scope for streamlining 
cumbersome licensing processes so as to facilitate a flexible adjustment of housing supply to demand conditions.

43. From a taxation perspective, well-designed taxes on under-used/vacant land could be imposed on landowners to encourage residential development in countries with a shortage of land for residential construction. For example, linking the assessment of property value for tax purposes to the market value may increase incentives for developing vacant land (Johansson et al., 2008). In countries where the construction industry is characterised by a few large constructors, competition policy hindering collusive behaviour in the construction sector is also important for a flexible supply. The design of such policies should, however, balance the benefit of additional supply against the potential cost of new developments in terms of congestion and environmental amenity losses. 


\section{REFERENCES}

André, C. (2010), “A Bird's Eye View of OECD Housing Markets”, OECD Economics Department Working Papers 746, OECD, Paris.

Andrews, D., A. Caldera Sánchez and Å. Johansson (2011), "Housing markets and structural policies in OECD countries”, OECD Economics Department Working Papers, forthcoming, OECD, Paris

Andrews, D. (2010), "Real House Prices in OECD Countries -- The Role of Demand Shocks and Structural and Policy Factors”, OECD Economics Department Working Papers, No. 813, OECD, Paris.

Caldera Sánchez, A. and D. Andrews (2011), “To Move or Not to Move: What Drives Residential Mobility in the OECD?” OECD Economics Department Working Papers, forthcoming, OECD, Paris.

Arnott, R. (1995), “Time for Revisionism on Rent Control?”, Journal of Economic Perspectives, Vol. 9, Issue 1, pp. 99-120

Arnott, R. (2003), “Tenancy Rent Control”, Swedish Economic Policy Review, Vol. 10, No.10, pp. 89-121.

Banarjee, A., J. Dolado, J.W. Galbraight and D. Hendry (1993), “Cointegration, Error Correction and the Econometric Analysis of Non-Stationary Data”, Oxford University Press.

Barker, K. (2004), “Review of Housing Supply”, HM Treasury, United Kingdom, http://www.barkerreview.org.uk/ .

Barker, K. (2008), “Planning Policy, Planning Practice, and Housing Supply”, Oxford Review of Economic Policy, Vol. 24 (1), pp. 34-49.

Bouis, R. and C. Klein (2009), "La concurrence favorise-t-elle les gains de productivité ? Une analyse sectorielle dans les pays de l’OCDE" Économie et statistique $N^{\circ} 419-420$.

Cameron, G. and J. Muellbauer (1998), “The Housing Market and Regional Migration and Community Choices”, Scottish Journal of Political Economy, 45(4), pp.420-446.

DiPasquale, D. (1999), “Why Don't We Know More about Housing supply?”, Journal of Real State Finance and Economics, Vol. 18, pp.9-23.

DiPasquale, D. and W. Wheaton (1994), "Housing Market Dynamics and the Future of Housing Prices", Journal of Urban Economics, Vol. 35, Issue 1, pp. 1-27.

Ellingsen, T. and P. Englund (2003), “Rent Regulation: An Introduction”, Swedish Economic Policy Review, Vol. 10, pp.3-9.

Engle, R. F. and C.W.J. Granger (1987), “Cointegration and Error Correction: Representation, Estimation, and Testing”, Econometrica, 55: pp. 251-276.

Favara, G. and J. Imbs (2009), “Credit Supply and the Price of Housing”, Unpublished Mimeo.

Glaeser , E.L., J. Gyurko and A; Saiz (2008), “Housing Supply and Housing Bubbles”, NBER Working Paper No. 14193. 
Green, RK, S. Malpezzi and S.K. Mayo (2005), "Metropolitan-Specific Estimates of the Price Elasticity of Supply of Housing, and Their Sources”, American Economic Review 95(2): 334-339.

Grimes, A. and A. Aitken (2006), "Housing Supply and Price Adjustment", Working Papers 06_01, Motu Economic and Public Policy Research.

Gyourko, J. (2009), “Housing Supply”, Annual Review of Economics, Vol 1, pp. 295-318.

Harter-Dreiman, M. (2004). "Drawing Inferences About Housing Supply Elasticity from House Price Responses to Income Shocks”, Journal of Urban Economics, 55(2), 316 - 337.

Hüfner , F. and J. Lundsgaard (2007), "The Swedish Housing Market: Better Allocation via Less Regulation”, OECD Economics Department Working Papers No. 559, OECD, Paris.

Johansson, Å., C. Heady, J. Arnold, B. Brys and L. Vartia (2008), "Taxation and Economic Growth” OECD Economics Department Working Papers, no.620, OECD, Paris

Malpezzi, S. (1996), “Housing Prices, Externalities, and Regulation in U.S. Metropolitan Areas”, Journal of Housing Research 7(2): 209-241.

Mayer, C. and T. Somerville (2000), “Land Use Regulation and New Construction?", Regional Science and Urban Economics, December, Vol. 30, No. 6, pp. 639-62.

Mayo, S. and S. Sheppard (1994), “Housing Supply Under Rapid Economic Growth and Varying Regulatory Stringency: An International Comparison”, Journal of Housing Economics, 5(3), pp. 274-289.

Meen, G. (2002), “The Time-Series Behavior of House Prices: A Transatlantic Divide?”, Journal of Housing Economics Vol. 11 (1), pp. 1-23.

Molnár, M. and N. Bottini (2010), “How Large are Competitive Pressures in Services Markets? Estimation of Mark-Ups for Selected OECD Countries”, OECD Economic Studies, forthcoming.

Ng, S. and P. Perron (2001), "Lag Selection and the Construction of Unit Root Tests with Good Size and Power”, Econometrica, Vol. 69, pp. 1519-1554.

OECD (2008), Policy Roundtables, Construction Industry, Paris http://www.oecd.org/dataoecd/32/55/41765075.pdf.

Poterba, J. (1984), “Tax Subsidies to Owner Occupied Housing: An Asset Market Approach”, Quarterly Journal of Economics, Vol. 99, pp. 729-752

Rae, D. and P. van den Nord (2006), "Ireland's Housing Boom: What has Driven it and Have Prices Overshot?”, OECD Economics Department Working Papers No. 492, OECD, Paris.

Saks, R, (2008), "Job Creation and Housing Construction: Constraints on Metropolitan Area Employment Growth”, Journal of Urban Economics, Vol. 64 (1), pp.178-195.

Sims, D. (2007), “Out of Control: What Can We Learn from the End of Massachusetts Rent Control?”, Journal of Urban Economics, Vol. 61 (1), pp. 129-151.

Swank, J., J. Kanes and A Tieman (2002), “The Housing Ladder, Taxation, and Borrowing Constraints”, Netherlands Central Bank, No. 2002-9.

Taltavull De La Paz, P. (2008), "The Housing Supply in Spain", paper presented at the ENHR seminar on Housing Economics (Feb.), Copenhagen.

Topel, R. and S. Rosen (1988), “Housing Investment in the United States”, Journal of Political Economy, 96 (4), pp. 718-740. 
Vermeulen, W. and J. Rouwendal (2007), "Housing Supply and Land Use Regulation in the Netherlands", Tinbergen Institute Discussion Papers 07-058/3, Tinbergen Institute.

\section{APENDIX 1: ADDITIONAL TABLES}

Table A1. Variable description

\begin{tabular}{|c|c|c|}
\hline Variable & Description & Source \\
\hline Real house prices & $\begin{array}{l}\text { Housing price, real, deflated by the } \\
\text { consumer price index }\end{array}$ & $\begin{array}{l}\text { OECD MEI database and } \\
\text { National sources }\end{array}$ \\
\hline Consumer price index & Consumer price index & OECD ADB database \\
\hline Real construction costs & $\begin{array}{l}\text { Construction cost, real, deflated by the } \\
\text { GDP deflator }\end{array}$ & $\begin{array}{l}\text { OECD MEI database and } \\
\text { National sources }\end{array}$ \\
\hline Dw elling stock & Total dw elling stock & UNECE \\
\hline $\begin{array}{l}\text { Short term interest } \\
\text { rates }\end{array}$ & Real short-term interest rate & OECD ADB database \\
\hline $\begin{array}{l}\text { Long term interest } \\
\text { rates }\end{array}$ & Real long-term interest rate & OECD ADB database \\
\hline Residential investment & Gross fixed investment, housing & OECD ADB database \\
\hline Population 25-44 & Population betw een $25-44$ years old & United Nations \\
\hline Total population & Population total & United Nations \\
\hline GDP & GDP volume at 2005 PPP, US\$ & OECD ADB database \\
\hline Disposable income & $\begin{array}{l}\text { Net household disposable income, } \\
\text { value }\end{array}$ & OECD ADB database \\
\hline
\end{tabular}


ECO/WKP(2011)6

Table A2. Augmented Dickey Fuller test ${ }^{1}$

\begin{tabular}{|c|c|c|c|c|c|c|}
\hline & \multicolumn{2}{|c|}{ Australia } & \multicolumn{2}{|c|}{ Austria } & \multicolumn{2}{|c|}{ Belgium } \\
\hline & Level & $\begin{array}{c}1 \text { st } \\
\text { difference }\end{array}$ & Level & $\begin{array}{c}1 \text { st } \\
\text { difference }\end{array}$ & Level & $\begin{array}{c}1 \text { st } \\
\text { difference }\end{array}$ \\
\hline Log real house prices & -0.869 & $-4.792^{\star \star \star}$ & -2.943 & $-1.682^{*}$ & -0.729 & $-1.447^{*}$ \\
\hline Log residential investment & $-5.301^{\star \star \star}$ & $-6.746^{\star \star \star}$ & -2.010 & $-4.490^{\star \star \star}$ & -3.048 & $-3.068^{\star \star \star}$ \\
\hline Log GDP & -2.487 & $-4.274^{\star \star \star}$ & $-3.175^{\star}$ & $-6.021^{\star \star \star}$ & -3.187 & $-3.548^{\star \star *}$ \\
\hline Log GDP per capita & -2.054 & $-4.161^{\star \star \star}$ & -2.551 & $-5.922^{\star \star \star}$ & -2.325 & $-3.433^{\star \star \star}$ \\
\hline Log disposable income & -1.148 & $-4.358^{\star \star \star}$ & -2.320 & $-2.974^{\star \star \star}$ & -3.236 & $-3.332^{\star \star \star}$ \\
\hline Log disposable income per capita & -0.722 & $-4.148^{\star \star \star}$ & -2.204 & $-2.839 * \star \star$ & $-3.203^{*}$ & $-3.404^{\star \star \star}$ \\
\hline Weighted average short term and long term interest rates & -1.700 & $-4.508^{\star \star \star}$ & -1.982 & $-4.334^{\star \star \star}$ & -2.720 & $-9.074^{\star \star \star}$ \\
\hline Short term interest rates & -1.700 & $-4.508^{\star \star \star}$ & -2.677 & $-8.112^{\star \star \star}$ & -2.058 & $-3.215^{\star \star \star}$ \\
\hline Long term interest rates & -1.726 & $-4.070^{* \star *}$ & -2.159 & $-4.387^{\star * \star}$ & -2.764 & $-8.780^{\star \star \star}$ \\
\hline Log real construction costs & -2.516 & $-4.299^{\star \star \star}$ & -2.798 & $-6.349^{\star \star \star}$ & -2.383 & $-7.375^{\star \star \star}$ \\
\hline Log total population & -1.422 & $-1.888^{*}$ & $-3.596^{\star \star}$ & -0.600 & -1.420 & -1.194 \\
\hline Log population aged $25-44$ & $-3.680^{\star \star}$ & -1.087 & $-4.119^{\star \star \star}$ & -1.192 & $-3.616^{\star \star \star}$ & -0.460 \\
\hline Share of the total population aged $25-44$ & $-3.962^{\star \star}$ & -0.562 & -2.042 & -0.634 & $-4.059^{\star \star *}$ & -0.541 \\
\hline
\end{tabular}

\begin{tabular}{|c|c|c|c|c|c|c|}
\hline & \multicolumn{2}{|c|}{ Canada } & \multicolumn{2}{|c|}{ Denmark } & \multicolumn{2}{|c|}{ Finland } \\
\hline & Level & $\begin{array}{c}1 \text { st } \\
\text { difference }\end{array}$ & Level & $\begin{array}{c}1 \text { st } \\
\text { difference }\end{array}$ & Level & $\begin{array}{c}1 \text { st } \\
\text { difference }\end{array}$ \\
\hline Log real house prices & -2.776 & $-2.822^{\star \star \star}$ & -1.724 & $-3.730^{\star \star \star}$ & -2.572 & $-3.985^{\star \star \star}$ \\
\hline Log residential investment & -2.219 & $-6.125^{\star \star \star}$ & -1.887 & $-4.273^{\star \star \star}$ & -2.993 & $-3.509^{\star \star \star}$ \\
\hline Log GDP & -2.238 & $-3.432^{\star \star *}$ & -2.436 & $-3.278^{\star \star \star}$ & 2.665 & $-3.912^{\star \star \star}$ \\
\hline Log GDP per capita & -2.262 & $-3.374^{\star \star \star}$ & -1.972 & $-3.231^{\star \star *}$ & -2.638 & $-3.887^{* \star *}$ \\
\hline Log disposable income & $-3.592^{\star \star}$ & $-3.783^{\star \star \star}$ & -2.248 & $-4.579^{\star \star \star}$ & -2.114 & $-3.911^{\star \star \star}$ \\
\hline Log disposable income per capita & $-3.410^{*}$ & $-3.832^{\star \star \star}$ & -3.136 & $-4.484^{\star \star \star}$ & -2.124 & $-3.864^{\star \star \star}$ \\
\hline Weighted average short term and long term interest rates & -2.072 & $-8.374^{\star \star \star}$ & -2.910 & $-4.855^{\star \star \star}$ & -2.202 & $-9.314^{\star \star *}$ \\
\hline Short term interest rates & -1.577 & $-5.854^{\star \star \star}$ & -2.371 & $-3.660^{\star \star \star}$ & -2.2 & $-9.295^{\star \star \star}$ \\
\hline Long term interest rates & -2.079 & $-8.249^{\star \star \star}$ & -1.897 & $-6.224^{\star \star \star}$ & -2.313 & $-9.263^{\star \star \star}$ \\
\hline Log real construction costs & -2.590 & $-4.130^{* \star \star}$ & -3.008 & $-5.028^{\star \star \star}$ & -1.425 & $-2.652^{\star \star \star}$ \\
\hline Log total population & -0.956 & $-1.652^{\star}$ & $-4.567^{\star \star \star}$ & $-2.523^{\star \star \star}$ & $-1.429^{\star}$ & -1.202 \\
\hline Log population aged 25-44 & $-3.615^{\star \star}$ & -1.405 & -0.817 & -0.010 & $-3.513^{\star \star *}$ & $-1.370^{\star}$ \\
\hline Share of the total population aged $25-44$ & $-4.041^{\star \star \star}$ & -0.889 & -1.741 & -0.476 & -1.370 & $-1.387^{*}$ \\
\hline
\end{tabular}

\begin{tabular}{|c|c|c|c|c|c|c|}
\hline & \multicolumn{2}{|c|}{ France } & \multicolumn{2}{|c|}{ Germany } & \multicolumn{2}{|c|}{ Ireland } \\
\hline & Level & $\begin{array}{c}\text { 1st } \\
\text { difference }\end{array}$ & Level & $\begin{array}{c}\text { 1st } \\
\text { difference }\end{array}$ & Level & $\begin{array}{c}\text { 1st } \\
\text { difference }\end{array}$ \\
\hline Log real house prices & -3.090 & $-2.752^{\star \star \star}$ & -1.644 & $-3.415^{\star \star \star}$ & -1.767 & $-3.491^{\star \star \star}$ \\
\hline Log residential investment & -2.524 & $-3.722^{\star \star \star}$ & -2.252 & $-5.522^{\star \star \star}$ & -1.804 & $-4.173^{\star \star \star}$ \\
\hline Log GDP & -2.830 & $-4.208^{\star \star \star}$ & -1.546 & $-4.153^{\star \star \star}$ & -1.833 & $-2.211^{\star \star *}$ \\
\hline Log GDP per capita & -2.544 & $-4.277^{\star \star \star}$ & -1.698 & $-4.303^{\star \star \star}$ & -1.864 & $-1.336^{*}$ \\
\hline Log disposable income & -3.086 & $-4.371^{\star \star \star}$ & -0.652 & $-2.851^{\star * *}$ & -1.361 & -3.755 \\
\hline Log disposable income per capita & -3.118 & $-4.363^{\star * *}$ & -0.450 & $-3.007^{\star \star \star}$ & -1.408 & $-1.922^{\star *}$ \\
\hline Weighted average short term and long term interest rates & -1.724 & $-7.461^{\star \star \star}$ & -2.591 & $-5.720^{\star \star *}$ & -1.625 & $-6.021^{\star \star \star}$ \\
\hline Short term interest rates & -1.588 & 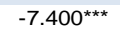 & -2.230 & $-5.884^{\star \star \star}$ & -1.924 & $-5.958^{\star \star \star}$ \\
\hline Long term interest rates & -1.816 & $-7.411^{\star \star \star}$ & -2.591 & $-5.720^{\star \star \star}$ & -2.217 & $-4.354^{\star \star \star}$ \\
\hline Log real construction costs & -0.869 & $-2.339^{\star \star \star}$ & -2.676 & $-3.526^{\star \star \star}$ & -2.544 & $-8.761^{\star \star \star}$ \\
\hline Log total population & -2.113 & $-2.789^{\star \star \star}$ & $-4.154^{\star \star \star}$ & -1.356 & $-6.646^{\star \star \star}$ & -1.302 \\
\hline Log population aged $25-44$ & $-3.491^{\star \star \star}$ & -0.249 & $-3.135^{\star \star \star}$ & -0.524 & $-4.807^{\star \star \star}$ & -0.440 \\
\hline \multirow[t]{3}{*}{ Share of the total population aged $25-44$} & $-3.799^{\star \star \star}$ & -0.329 & $-3.285^{\star \star \star}$ & -0.595 & $-3.519^{\star \star \star}$ & -0.555 \\
\hline & \multicolumn{2}{|c|}{ Israel } & \multicolumn{2}{|c|}{ Italy } & \multicolumn{2}{|c|}{ Japan } \\
\hline & Level & $\begin{array}{c}1 s t \\
\text { difference }\end{array}$ & Level & $\begin{array}{c}1 s t \\
\text { difference }\end{array}$ & Level & $\begin{array}{c}1 \text { st } \\
\text { difference }\end{array}$ \\
\hline Log real house prices & $-3.535^{\star}$ & $-2.592^{\star \star}$ & $-3.848^{\star \star}$ & $-2.957^{\star \star \star}$ & 0.223 & $-4.391^{\star \star \star}$ \\
\hline Log residential investment & -0.294 & $-3.206^{\star \star \star}$ & -2.867 & $-4.146^{\star \star \star}$ & -0.686 & $-2.966^{\star \star \star}$ \\
\hline Log GDP & -2.077 & $-2.839^{\star \star \star}$ & -0.767 & $-2.207^{\star \star \star}$ & 0.070 & $-2.823^{\star \star \star}$ \\
\hline Log GDP per capita & .. & .. & 0.181 & $-2.121^{\star \star \star}$ & -0.093 & $-3.511^{\star \star \star}$ \\
\hline Log disposable income & .. & .. & -1.830 & $-2.628^{\star \star \star}$ & -1.225 & $-2.987^{\star \star \star}$ \\
\hline Log disposable income per capita & .. & .. & -1.310 & $-2.647^{\star \star \star}$ & -1.397 & $-3.084^{\star \star \star}$ \\
\hline Weighted average short term and long term interest rates & .. & .. & -1.825 & 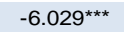 & -1.709 & $-4.627^{\star \star \star}$ \\
\hline Short term interest rates & -2.925 & $-3.416^{\star \star *}$ & -1.813 & $-6.027^{\star \star \star}$ & -1.685 & $-4.695^{\star \star \star}$ \\
\hline Long term interest rates & .. & .. & -2.182 & $-5.566^{\star \star \star}$ & -1.806 & $-4.717^{\star \star \star}$ \\
\hline Log real construction costs & -1.181 & $-1.945^{\star *}$ & -2.613 & $-4.103^{\star \star \star}$ & -2.086 & $-1.986^{\star \star}$ \\
\hline Log total population & -0.582 & $-2.596^{\star *}$ & $-3.237^{\star \star \star}$ & -1.519 & -1.671 & $-6.205^{\star \star \star}$ \\
\hline Log population aged $25-44$ & .. & .. & $-3.185^{\star \star \star}$ & -0.612 & $-3.292^{*}$ & $-2.866^{\star \star \star}$ \\
\hline Share of the total population aged $25-44$ & .. & .. & $-3.952^{\star \star *}$ & -0.876 & $-4.967^{\star \star \star *}$ & -1.580 \\
\hline
\end{tabular}

1. ${ }^{* \star *}$ stationary at $1 \%$ level of significance. ${ }^{* *}$ stationary at $5 \%$ level of significance. ${ }^{*}$ stationary at $10 \%$ level of significance.

Source: OECD estimates. 
Table A2. Augmented Dickey Fuller test ${ }^{1}$ (cont'd)

\begin{tabular}{|c|c|c|c|c|c|c|}
\hline & \multicolumn{2}{|c|}{ Netherlands } & \multicolumn{2}{|c|}{ New Zealand } & \multicolumn{2}{|c|}{ Norway } \\
\hline & Level & $\begin{array}{c}1 \text { st } \\
\text { difference }\end{array}$ & Level & $\begin{array}{c}\text { 1st } \\
\text { difference }\end{array}$ & Level & $\begin{array}{c}\text { 1st } \\
\text { difference }\end{array}$ \\
\hline Log real house prices & -2.508 & $-2.920^{\star \star \star}$ & -3.078 & $-3.242^{\star \star \star}$ & -1.977 & $-3.049^{\star \star \star}$ \\
\hline Log residential investment & -2.300 & $-8.000^{* \star *}$ & -2.633 & $-3.141^{\star \star \star}$ & -2.058 & $-3.569^{\star \star \star}$ \\
\hline Log GDP & -1.751 & $-3.061^{\star \star \star}$ & -2.584 & $-2.738^{\star \star \star}$ & -1.513 & $-2.921^{\star \star \star}$ \\
\hline Log GDP per capita & -1.846 & $-9.183^{\star \star \star}$ & -2.570 & $-2.835^{\star \star \star}$ & -0.830 & $-2.695^{\star \star \star}$ \\
\hline Log disposable income & -2.796 & $-3.003^{\star \star \star}$ & -3.637 & $-2.040^{\star \star}$ & -1.380 & $-5.136^{\star \star \star}$ \\
\hline Log disposable income per capita & -2.704 & $-3.059^{\star \star \star}$ & $-3.361^{*}$ & $-2.035^{\star \star}$ & -1.613 & -5.158 *** \\
\hline Weighted average short term and long term interest rates & -1.729 & $-7.962^{\star \star \star}$ & -3.082 & $-8.842^{\star \star \star}$ & $-3.590 \star \star$ & $-4.801^{\star \star *}$ \\
\hline Short term interest rates & -2.002 & $-6.583^{\star \star \star}$ & -2.222 & $-6.828^{\star \star \star}$ & $-3.590^{\star \star}$ & $-4.801^{\star \star \star}$ \\
\hline Long term interest rates & -1.780 & $-7.949 * \star \star$ & -3.082 & $-8.842^{\star \star \star}$ & -1.452 & $-7.142^{\star \star \star}$ \\
\hline Log real construction costs & -2.395 & $-4.512^{\star \star \star}$ & -1.646 & $-6.348^{\star \star \star}$ & -2.227 & 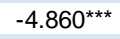 \\
\hline Log total population & -0.277 & $-2.192^{\star \star}$ & $-6.100^{\star * *}$ & -1.923 & -1.827 & $-1.867^{\star \star}$ \\
\hline Log population aged $25-44$ & $-3.773^{\star \star \star}$ & -0.036 & $-4.061^{\star \star \star}$ & -0.081 & $-3.806^{\star \star}$ & 0.256 \\
\hline Share of the total population aged $25-44$ & $-5.789 * \star \star$ & -0.599 & $-5.735^{\star \star \star}$ & -1.443 & $-3.192^{\star}$ & 0.370 \\
\hline
\end{tabular}

\begin{tabular}{|c|c|c|c|c|c|c|}
\hline & \multicolumn{2}{|c|}{ Poland } & \multicolumn{2}{|c|}{ Spain } & \multicolumn{2}{|c|}{ Sweden } \\
\hline & Level & $\begin{array}{c}1 \text { st } \\
\text { difference }\end{array}$ & Level & $\begin{array}{c}\text { 1st } \\
\text { difference }\end{array}$ & Level & $\begin{array}{c}\text { 1st } \\
\text { difference }\end{array}$ \\
\hline Log real house prices & -0.546 & $-2.533^{\star \star \star}$ & $-3.162^{\star}$ & $-2.919^{\star \star \star}$ & -1.302 & $-2.596^{\star \star \star}$ \\
\hline Log residential investment & -3.095 & $-1.689^{*}$ & -2.810 & $-1.673^{\star \star}$ & -2.908 & $-2.973^{\star \star \star}$ \\
\hline Log GDP & $-3.776^{\star \star}$ & $-6.463^{\star \star \star}$ & -2.678 & $-3.101^{\star \star \star}$ & -2.322 & $-3.772^{\star \star \star}$ \\
\hline Log GDP per capita & $-4.24^{\star \star \star}$ & $-6.382^{\star \star \star}$ & -2.305 & $-2.954^{\star \star \star}$ & -2.614 & $-4.821^{\star \star *}$ \\
\hline Log disposable income & $-4.490 * \star \star$ & $-10.041^{\star * *}$ & -2.748 & $-2.986^{\star \star *}$ & -1.249 & $-3.675^{\star \star \star}$ \\
\hline Log disposable income per capita & $-4.442^{\star \star \star}$ & $-10.088^{\star \star *}$ & -2.700 & $-2.894^{\star \star *}$ & -1.371 & $-3.755^{\star \star \star}$ \\
\hline Weighted average short term and long term interest rates & -1.357 & $-4.514^{\star \star \star}$ & $-5.151^{\star \star \star}$ & $-8.785^{\star \star \star}$ & $-5.635^{\star \star \star}$ & $-10.446^{\star \star \star}$ \\
\hline Short term interest rates & -1.357 & $-4.514^{\star \star \star}$ & -2.517 & $-5.996^{\star \star \star}$ & $-8.506^{\star \star \star}$ & $-17.735^{\star \star \star}$ \\
\hline Long term interest rates & -2.223 & $-1.358^{*}$ & -2.784 & $-11.571^{\star \star \star}$ & -1.172 & $-5.826^{\star \star \star}$ \\
\hline Log real construction costs & -2.790 & $-2.362^{\star *}$ & -1.981 & $-7.195^{\star \star \star}$ & -2.672 & $-3.008^{\star \star \star}$ \\
\hline Log total population & $-6.151^{\star \star *}$ & $-1.384^{*}$ & $-6.101^{\star \star \star}$ & $-2.010^{* *}$ & $-3.832^{\star \star}$ & $-1.796^{\star \star}$ \\
\hline Log population aged $25-44$ & $-3.320^{*}$ & $-1.595^{\star \star}$ & -2.254 & $-1.787^{\star \star}$ & $-3.690 * \star$ & $-2.312^{\star \star}$ \\
\hline Share of the total population aged $25-44$ & $-4.297^{\star \star \star}$ & $-1.978^{\star \star}$ & -2.505 & $-1.304^{*}$ & -3.021 & $-1.368^{*}$ \\
\hline
\end{tabular}

\begin{tabular}{|c|c|c|c|c|c|c|}
\hline & \multicolumn{2}{|c|}{ Switzerland } & \multicolumn{2}{|c|}{ United Kingdom } & \multicolumn{2}{|c|}{ United States } \\
\hline & Level & $\begin{array}{c}1 \text { st } \\
\text { difference }\end{array}$ & Level & $\begin{array}{c}1 \text { st } \\
\text { difference }\end{array}$ & Level & $\begin{array}{c}\text { 1st } \\
\text { difference }\end{array}$ \\
\hline Log real house prices & -2.795 & $-3.624^{\star \star \star}$ & $-3.601^{\star \star}$ & $-3.449^{\star \star \star}$ & -1.088 & $-3.396^{\star \star \star}$ \\
\hline Log residential investment & -1.925 & $-4.212^{\star \star \star}$ & -2.621 & $-3.655^{\star \star \star}$ & $-4.297^{\star \star \star}$ & $-4.007^{\star \star \star}$ \\
\hline Log GDP & $-3.673^{\star \star}$ & $-3.969^{\star \star \star}$ & -2.977 & $-3.323^{\star \star \star}$ & -2.392 & $-4.166^{\star \star \star}$ \\
\hline Log GDP per capita & $-3.721^{\star \star}$ & $-4.014^{\star \star \star}$ & -3.047 & $-3.268^{\star \star \star}$ & -2.096 & $-4.292^{\star \star \star}$ \\
\hline Log disposable income & $-3.367^{\star}$ & $-3.203^{\star \star \star}$ & -2.440 & $-4.514^{\star \star \star}$ & -2.207 & $-4.572^{\star \star \star}$ \\
\hline Log disposable income per capita & $-3.249^{*}$ & $-3.278^{\star \star \star}$ & -2.215 & $-4.482^{\star \star \star}$ & -1.892 & $-4.679 * \star \star$ \\
\hline Weighted average short term and long term interest rates & -3.135 & $-7.471^{\star \star \star}$ & -1.866 & $-6.108^{\star \star \star}$ & -2.524 & $-7.798^{\star \star \star}$ \\
\hline Short term interest rates & -3.135 & $-7.471^{\star \star \star}$ & -1.844 & $-6.103^{\star \star \star}$ & -2.803 & $-9.152^{\star * \star}$ \\
\hline Long term interest rates & $-4.225^{\star \star \star}$ & $-3.567^{\star \star \star *}$ & -3.030 & $-9.047^{\star \star *}$ & -2.530 & $-7.483^{\star \star \star}$ \\
\hline Log real construction costs & -2.004 & $-3.905^{\star \star \star}$ & -1.901 & $-4.437^{\star \star \star}$ & -0.544 & $-4.532^{\star \star \star}$ \\
\hline Log total population & $-5.226^{\star * \star}$ & -1.275 & -0.684 & -0.648 & $-6.637^{\star \star *}$ & $-1.751^{\star *}$ \\
\hline Log population aged $25-44$ & -1.444 & -0.429 & -1.410 & -0.084 & $-5.061 * \star \star$ & $-1.378^{\star}$ \\
\hline Share of the total population aged $25-44$ & -1.345 & 0.256 & -1.403 & 0.158 & $-4.492^{\star \star \star}$ & $-1.599^{*}$ \\
\hline
\end{tabular}

1. ${ }^{* \star *}$ stationary at $1 \%$ level of significance. ${ }^{* \star}$ stationary at $5 \%$ level of significance. ${ }^{*}$ stationary at $10 \%$ level of significance.

Source: OECD estimates. 


\section{WORKING PAPERS}

The full series of Economics Department Working Papers can be consulted at www.oecd.org/eco/workingpapers/

836. Housing markets and structural policies in OECD countries

(January 2011) by Dan Andrews, Aida Caldera Sánchez and Åsa Johansson

835. Raising potential growth after the crisis: A quantitative assessment of the potential gains from various structural reforms in the OECD area and beyond (January 2011) by Romain Bouis and Romain Duval

834. The GDP impact of reform: a simple simulation framework

(January 2011) by Sebastian Barnes, Romain Bouis, Philippe Briard, Sean Dougherty and Mehmet Eris

833. Improving the flexibility of the Dutch housing market to enhance labour mobility (January 2011) by Jens Høj

832. Making the Dutch pension system less vulnerable to financial crises (January 2011) by Jens Høj

831. Real house prices in OECD countries: the role of demand shocks and structural policy factors

(December 2010) by Dan Andrews

830. International financial integration and the external positions of euro area countries (December 2010) by Philip R. Lane

829. Improving fiscal performance through fiscal councils (December 2010) by Robert Hagemann

828. Minimising risks from imbalances in European banking

(December 2010) by Sebastian Barnes, Philip Lane and Artur Radziwill

827. Resolving and avoiding unsustainable imbalances

(December 2010) by Sebastian Barnes

826. Current account imbalances in the euro area: a comparative perspective (December 2010) by Sebastian Barnes, Jeremy Lawson and Artur Radziwill

825. Does fiscal decentralisation strengthen social capital? Cross-country evidence and the experiences of Brazil and Indonesia

(December 2010) by Luiz de Mello

824. Fiscal decentralisation and public investment: The experience of Latin America (December 2010) by Luiz de Mello 
823. Product market regulation and competition in China

(December 2010) by Paul Conway, Richard Herd, Thomas Chalaux, Ping He and Jianxun Yu

822. Reforming China's monetary policy framework to meet domestic objectives

(December 2010) by Paul Conway, Richard Herd and Thomas Chalaux

821. Regulatory reforms to unlock long-term growth in Turkey

(December 2010) by Rauf Gönenç and Łukasz Rawdanowicz

820. After the crisis: mitigating risks of macroeconomic instability in Turkey (December 2010) by Łukasz Rawdanowicz

819. The 2008-09 crisis in Turkey: performance, policy responses and challenges for sustaining the recovery

(December 2010) by Łukasz Rawdanowicz

818. Fiscal-consolidation strategies for Canadian governments (November 2010) by Yvan Guillemette

817. The land transport sector: policy and performance (November 2010) by Jan Persson and Daeho Song

816. A simple model of the relationship between productivity, saving and the current account (November 2010) by Jean-Marc Fournier, Isabell Koske

815. The impact of structural policies on saving, investment and current accounts (November 2010) by Clovis Kerdrain, Isabell Koske, Isabelle Wanner

814. Towards a less distortive and more efficient tax system in Portugal (November 2010) by Alvaro Pina

813. Are global imbalances sustainable? Shedding further light on the causes of current account reversals

(November 2010) by Luiz de Mello, Pier Carlo Padoan, Linda Rousová

812. Turkey's improving integration with the global capital market: Impacts on risk premia and capital costs

(November 2010) by Rauf Gönenç, Saygin Şahinöz, Özge Tuncel

811. Trade linkages in the OECD trade system

(October 2010) by Jérôme Brézillon, Stéphanie Guichard and Dave Turner

810. Enhancing the effectiveness of social policies in Indonesia

(October 2010) by Margherita Comola and Luiz de Mello

809. Tackling the infrastructure challenge in Indonesia

(October 2010) by Mauro Pisu 